\title{
静水圧型外荷重を受ける円弧アーチの安定問題
}

\section{1. 既往の研究と本論の目的}

薄肉弾性体, 特にシェル構造物についての弾性安定性 を検討する際に，その安定限界荷重を変動させる要因と しては種々考えられ，歴史的にもさまざまの要因がその 検討の対象として研究されてきている。シェル構造物の 弹性安定に関する研究については，主として実験值と理 論值の間のギャップを埋めるための努力そのものが, こ の分野の，ここ約 40 年の歴史であるといえよう。それ らの研究の中でも，最も精力的に研究されてきたものと して, 系の有する初期不整, 初期ひずみ, あるいは応力, さらには境界条件の影響に関する研究を挙げることがで きる。これらの諸要因は，系の安定限界状態に微妙に影 響を与えるもので，場合によっては，安定限界荷重を大 きく変動させる要因にもなり得るものであることが，こ れまでの研究報告により指摘されてきている11-5)。

本論で扱う, 荷重そのものの持つ特性に関しても，そ のような研究の歴史の中で問題意識が生まれ, 研究対象 となった。1942 年, H. Tsien ${ }^{6)}$ は, 等分布外珐を受け る球殼の安定解析を通して, 外力の特性の評価の相違, すなわち, 圧力型の外力の変形依存性を考慮するか否か の相違が，シェルの安定限界を変動させる場合があり， 系の持つ初期不整, 初期応力, あるいはひずみ, 境界条 件に対すると同様に検討を加えることが必要であること を指摘している。外力の特性と弾性体の安定問題とを, こうして明らかに関連付けて議論した研究報告は，おそ らくこれが最初のものであろう。その後, G. W. H. Stevens? ${ }^{7)}$ は，弾性师弧リングが，等分布荷重下に置か れた場合の限界荷重が，外力の評価方法によって，大き く変化することを示し，また，A.P. Boresi ${ }^{8)}$ は, Fig. 1-1 およびFig. 1-2 に示すように，円弧リングに 3 種頑 の異なった特性を持つ等分布外圧を加えた場合の弾性限 界を求め，これらが互いに異なる值となることを示して いる。また，G.A. Wempner と N.E. Kesti ${ }^{9}$ は，両端 固定の種々の開角を持つ円弧アーチが, Fig. 1-3 に示す ような 3 種類の荷重を受けた場合について，座屈時の軸 方向ひずみがないと考えた上で，線形固有值問題として

* 名古屋大学 助手 $\cdot$ 工博 (昭和 59 年 11 月 8 日原稿受理)

\section{正会員大森 博 司*}

これを解き, Table 1 に示すような弾性安定限界荷重を 求めている。この結果は, 外力の評価方法の相違により, 安定限界荷重に変動が生ずることを明確に示している。 さらに，C.Oran とR.S. Reagan ${ }^{10)}$ は，円弧アーチの 境界が，弾性支持された場合について，荷重の特性評価 法の相違により，限界値に複雑な変化が見られることを

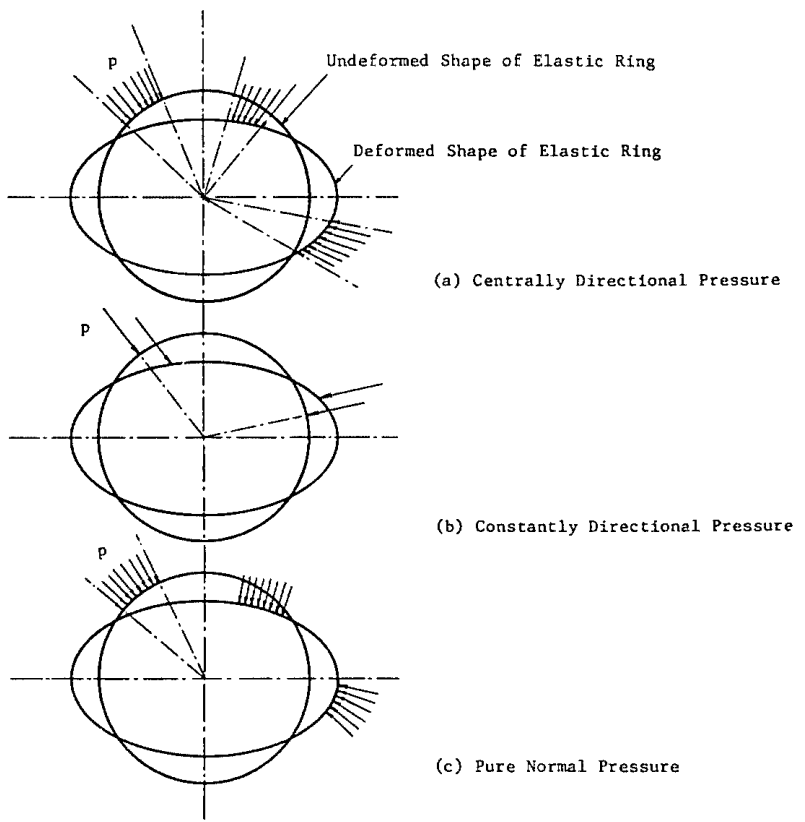

Fig. 1-1 Elastic Ring subjected to Three different Types of External Pressure ${ }^{8)}$

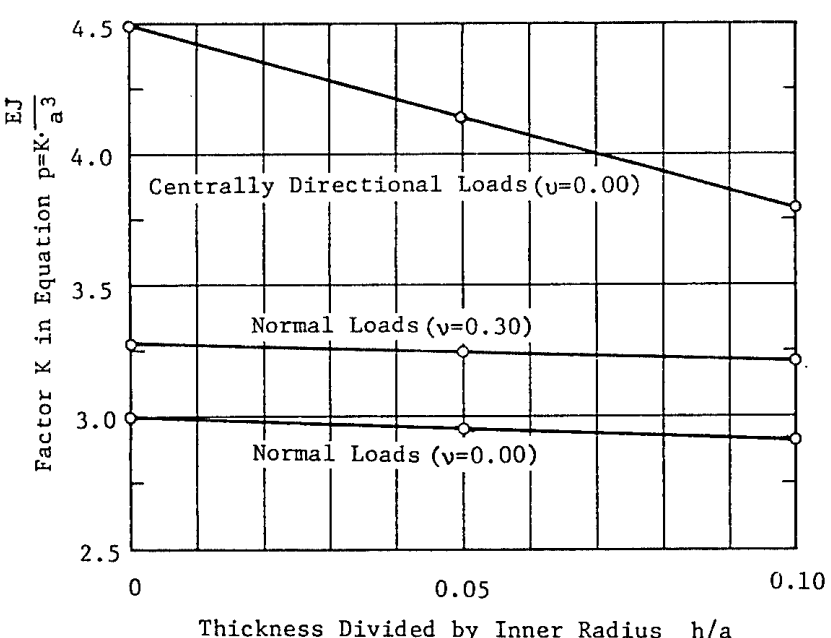

Fig. 1-2 $K$ versus $h / a^{8)}$ 


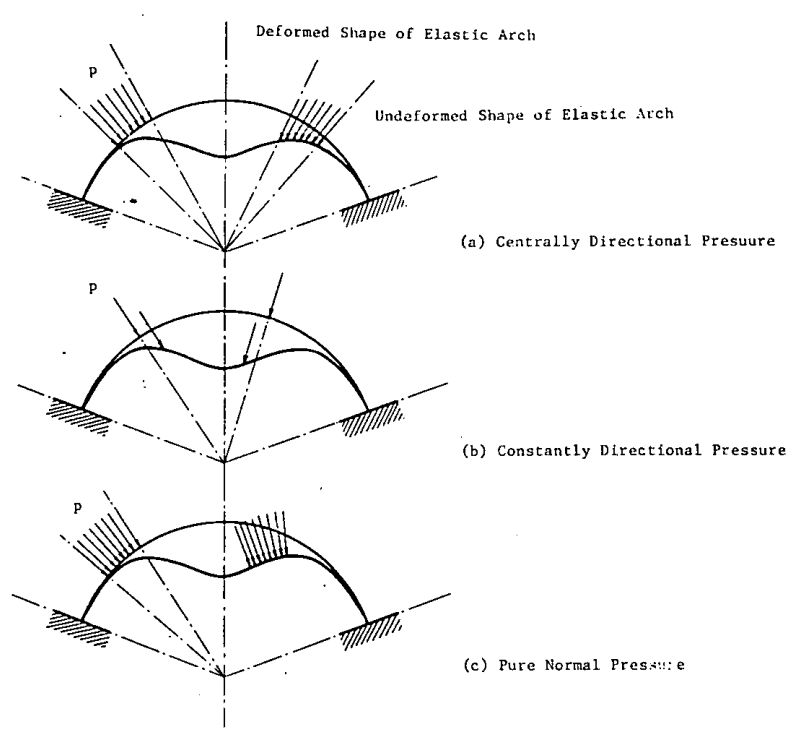

Fig. 1-3 Elastic Circular Arch subjected to Three Different Types of External Pressure ${ }^{9)}$

Table 1 Critical Loads of the Circular Arch ${ }^{9)}$

\begin{tabular}{|c|c|c|c|c|c|}
\hline \multirow{2}{*}{$\begin{array}{c}\text { E.rection } \\
\text { of } \\
\text { Load }\end{array}$} & \multicolumn{4}{|c|}{$\alpha$ : Opening Angle of the Arch } \\
\cline { 2 - 6 } & $30^{\circ}$ & $60^{\circ}$ & $90^{\circ}$ & $180^{\circ}$ & $\begin{array}{c}\text { Free } \\
\text { Ring }\end{array}$ \\
\hline Norma1 & 73.3 & 18.1 & 8.0 & 3.0 & 3.0 \\
\hline Constant & 80.5 & 19.4 & 9.0 & 5.6 & 4.0 \\
\hline Central & 80.5 & 20.2 & 10.9 & 6.5 & 4.5 \\
\hline
\end{tabular}

報告している。

変形依存型の外力が, 球形シェル, 円弧アーチ, ある いはリング等の弾性限界に影響を及ぼすことについて は，上述のように，いくつかの報告があるが，これらは， そのいずれもが, 線形固有值問題としての見地からの座 屈を扱うものであり, また, 座屈時において, 軸方向ひ ずみを起こさぬ,いわゆる伸びなし変形を仮定しており， 特に座屈前において, 非線形性を伴う曲げ変形を生ずる ような場合には，大きな誤差を生ずる可能性がある。ま た，これらの報告においては，外力の変形依存性を，幾 何学的な力のつり合条件から評価することにより基礎式 を定式化しているが，球形シェル，琱アーチあるいは リングのように，弾性体の境界が変形拘束 ${ }^{14)}$ を受けてい るようなものに作用する圧力型の外力は，ポテンシャル 力となり，これを直接離散化して基礎式とする正確な扱 いが可能である。

本論では, 両端ピン支持の円弧アーチを例題として, その定式化過程を示し, その結果求められる基礎式をも とにして, 外力を正確に評価した幾何学的非線形解析を 行い, 外力の変形依存性が, 系の弾性安定性状に及ぼす 影響について検討を加えるとともに, 弾性安定解析に多 用される固有関数展開を用いたノーマルモード法がこの
種の問題に適用された場合の精度を検討するために，有 限要素法を用いた場合との比較についても言及する。

\section{2. 静水圧型外カのポテンシャル表示}

本論では, シェル等の弾性体表面に対して, 法線方向 に作用する変形依存型外力の最も一般的なものとして静 水圧（従動型等分布荷重）を考え，以下これについての 定式化過程を示す。

2-1一般の曲線座標に対するポテンシャル表示

今, 静水圧型の外圧（厳密には液体の深度により変化 するが，ここではこの影響は考慮から除外し，一定とし て扱う）を受ける弾性体がすべての境界に変形拘束を受 けているものとすれば，単位表面積あたりに作用する外 王を $p$ (一定), それを受けて弾性体が変形し, その結果, その基準面が移動した部分（Fig.2-1で微小六面体 $\mathrm{P}^{\prime} \mathrm{Q}^{\prime} \mathrm{S}^{\prime} \mathrm{R}^{\prime}-\mathrm{PQRS}$ の部分) の体積を $\Delta V$ とすれば，外 力仕事 $\Delta W$ は次式で表される ${ }^{11)} 。$

$$
\Delta W=p \cdot \Delta V
$$

この表式から，静水圧型の外力の仕事量を求めるために は，弾性体の変形に伴って，その圧力を受ける表面が移 動した部分の体積変化量 $\Delta V$ を求めて, これに外王 $p$ を乗ずれば良いことが判る。このように考えれば，結局 問題は, Fig. 2-1において, 微小六面体 PQRS$P^{\prime} Q^{\prime} R^{\prime} S^{\prime}$ の体積を，変位ベクトル $\boldsymbol{u}$ によって表現する ことに帰着される。この図において，各ベクトルは，こ の曲線座標系の共変基底ペクトルを, $g_{1}, g_{2}$ とすると 次式のように表される。

$$
\begin{aligned}
& \overrightarrow{P P^{\prime}}=u, \overrightarrow{Q Q^{\prime}}=u+u_{, 1} \Delta x^{1} \\
& \overrightarrow{S S^{\prime}}=u+u_{, 2} \Delta x^{2}, \overrightarrow{R R^{\prime}}=u+u_{, 1} \Delta x^{1}+u_{, 2} \Delta x^{2} \\
& \overrightarrow{P Q}=g_{1} \Delta x^{1}, \overrightarrow{P S}=g_{2} \Delta x^{2}
\end{aligned}
$$

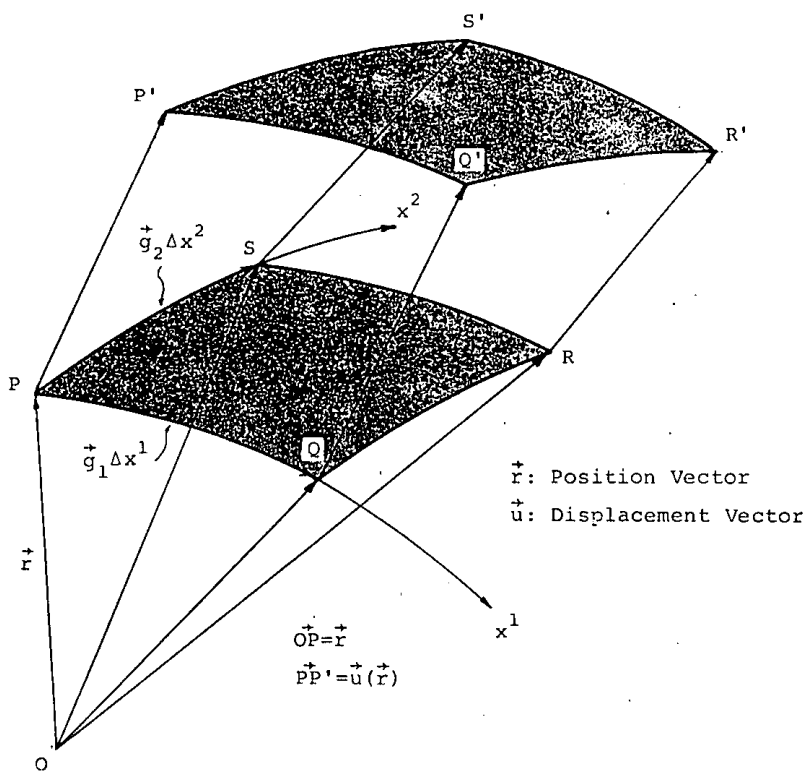

Fig. 2-1 Shift of the Infinitesimal Surface in the Curvilinear Coordinates 
ここに, $\boldsymbol{u}_{, i}=\partial u / \partial x^{i}$ を表す。

この表現を用いて微小六面体の体積を求めると, 高次 微小量を省略して次式を得る付永1。

$$
\begin{aligned}
\Delta V= & \boldsymbol{u} \cdot\left\{\boldsymbol{g}_{1} \times \boldsymbol{g}_{2}+\frac{1}{2}\left(\boldsymbol{u}_{, 1} \times \boldsymbol{g}_{2}-\boldsymbol{u}_{, 2} \times \boldsymbol{g}_{1}\right)\right. \\
& \left.+\frac{1}{3} \boldsymbol{u}_{, 1} \times \boldsymbol{u}_{, 2}\right\} \Delta x^{1} \Delta x^{2} \ldots \ldots \ldots \ldots \ldots \ldots \ldots \ldots
\end{aligned}
$$

ゆえに，全体積 $V$ は次式で表される。

$$
\begin{aligned}
V= & \int_{S} \boldsymbol{u} \cdot\left\{\boldsymbol{g}_{1} \times \boldsymbol{g}_{2}+\frac{1}{2}\left(\boldsymbol{u}_{, 1} \times \boldsymbol{g}_{2}-\boldsymbol{u}_{, 2} \times \boldsymbol{g}_{1}\right)\right. \\
& \left.+\frac{1}{3} \boldsymbol{u}_{, 1} \times \boldsymbol{u}_{, 2}\right\} d x^{1} d x^{2} \ldots \ldots \ldots \ldots \ldots \ldots \ldots \ldots \ldots \ldots
\end{aligned}
$$

テンソル表示では,

$$
\boldsymbol{u}=u^{i} \boldsymbol{g}_{i}, \quad \boldsymbol{u}_{, j}=u_{, j}^{i} \boldsymbol{g}_{i}+u^{i} \Gamma_{i j}^{i} \boldsymbol{g}_{k}
$$

であるからこれを（2-4）式に用いれば次式を得る。

$$
\begin{aligned}
V= & \int_{s}\left[\sqrt{g} u^{3}+\frac{1}{2}\left\{u^{k}\left(u_{, 1}^{i} \epsilon_{i 2 k}-u_{, 2}^{i} \epsilon_{i 1 k}\right)\right.\right. \\
& \left.+u^{i} u^{j}\left(\Gamma_{i 1}^{k} \epsilon_{k 2 j}-\Gamma_{i 2}^{k} \epsilon_{k 1}\right)\right\}+\frac{1}{3} u^{k}\left(u_{, 1}^{i} u_{, 2}^{j} \epsilon_{i j k}\right. \\
& +u_{, 1}^{i} u^{j} \Gamma_{j 2}^{l} \epsilon_{i l k}+u^{i} u_{, 2}^{j} \Gamma_{i 1}^{i} \epsilon_{l j k} \\
& \left.\left.+u^{i} u^{j} \Gamma_{i 1}^{m} \Gamma_{j 2}^{l} \epsilon_{m l k}\right)\right] d x^{1} d x^{2} \cdots \cdots \cdots \cdots \cdots(2-6)
\end{aligned}
$$

これが体積変化量を示すテンソル表示である。ただし， 共変基底ベクトル $\boldsymbol{g}_{i}$ の第 $j$ 成分を $g_{i j}$ とし, $g=\operatorname{det}$ $\left(g_{i j}\right)$ であり， $\Gamma_{i j}^{k}$ は Christoffel の記号, $\epsilon_{i j k}$ は Eddington の記号である。

2-2 一般の曲線座標によるつり合式の表示

弾性系の持つひずみエネルギーを $U$, 外力仕事を $W$ とすればつり合式は次式で表される。

$$
\delta(U-W)=0 \text { あるいは } \delta \boldsymbol{u} \cdot \operatorname{grad}(U-W)=0
$$

ここに, $\delta \boldsymbol{u}$ は変位べクトル $\boldsymbol{u}$ の第一変分, $\operatorname{grad}$ $(U-W)$ は汎関数 $\Pi=U-W の こ う$ 配 $^{19)}$ を表す。静水 圧型の外力を受ける場合, 単位面積あたりに作用する外 王を $p$ とすると, 外力の成す仕事 $W$ は, (2-4) 式から 次式で表される。

$$
\begin{aligned}
W= & p \int_{S} \boldsymbol{u} \cdot\left\{\boldsymbol{g}_{1} \times \boldsymbol{g}_{2}+\frac{1}{2}\left(\boldsymbol{u}_{, 1} \times \boldsymbol{g}_{2}-\boldsymbol{u}, 2 \times \boldsymbol{g}_{1}\right)\right. \\
& \left.+\frac{1}{3} \boldsymbol{u}_{, 1} \times \boldsymbol{u}_{, 2}\right\} d x^{1} d x^{2} \ldots \ldots \ldots \ldots \ldots \ldots \ldots
\end{aligned}
$$

変分をとると,

$$
\begin{aligned}
\delta W / p= & \int_{s} \delta \boldsymbol{u} \cdot\left\{\boldsymbol{g}_{1} \times \boldsymbol{g}_{2}+\boldsymbol{u}_{, 1} \times \boldsymbol{g}_{2}-\boldsymbol{u}_{, 2} \times \boldsymbol{g}_{1}+\boldsymbol{u}_{, 1}\right. \\
& \left.\times \boldsymbol{u}_{, 2}\right\} d x^{\prime} d x^{2}+\left[\int _ { \overline { x } _ { 2 } } ^ { \overline { x } ^ { 2 ^ { \prime } } } \delta \boldsymbol { u } \cdot \left(\frac{1}{2} \boldsymbol{g}_{2} \times \boldsymbol{u}\right.\right. \\
& \left.\left.+\frac{1}{3} \boldsymbol{u}_{, 2} \times \boldsymbol{u}\right) d x^{2}\right]_{x^{1}=\overline{\boldsymbol{x}}^{1}}^{x^{1}=\bar{x}^{\prime}}+\left[\int_{\bar{x}_{1}}^{\bar{x}^{2^{\prime}}} \delta \boldsymbol{u}\right. \\
& \left.+\left(\frac{1}{2} \boldsymbol{u} \times \boldsymbol{g}_{1}+\frac{1}{3} \boldsymbol{u} \times \boldsymbol{u}_{, 1}\right) d x^{1}\right]_{x^{2}=\bar{x}^{2}}^{x^{2}=\bar{x}^{2^{\prime}}}
\end{aligned}
$$

ここに, $\bar{x}^{1}, \bar{x}^{\prime \prime}, \bar{x}^{2}, \bar{x}^{2 \prime}$ はそれぞれ $x^{1}, x^{2}$ の変域境 界における指定された值であるものとする。 $\delta u$ が $x^{1}$ と $x^{2}$ の境界で消失することを考慮すると, 結局, つり合 式は次式で表現されることになる。

$$
\operatorname{grad} U-p\left(g_{1}+u_{1}\right) \times\left(g_{2}+u_{, 2}\right)=0
$$

あるいは,

$$
\begin{aligned}
& \operatorname{grad} U-p\left(\delta_{1}^{i}+u_{, 1}^{i}+u^{\kappa} \Gamma_{1 k}^{i}\right)\left(\delta_{2}^{j}+u_{, 2}^{j}\right. \\
& \left.\quad+u^{i} \Gamma_{2 l}^{j}\right) \epsilon_{i j m} g^{m}=0 \ldots \ldots \ldots \ldots \ldots \ldots \ldots \ldots \ldots \ldots \ldots \ldots \ldots
\end{aligned}
$$

(2-10) 式あるいは（2-11）式において, 第 2 項の外力 項の変位に関する項を取り除けば，通常の定方向型の王 力に対する基礎式となる。結局， $\left(g_{1}+u_{, 1}\right) \times\left(g_{2}+u_{, 2}\right)$ の 項は, 系が変形するこよにより, 外王 $p$ のかかる部分 の見つけの面積が変化することによる影響を表すものと 解釈することができる。

\section{3. 有限要素法による円弧アーチの弾性安定解析}

本章では，シェル構造物が面外方向に静水圧型の分布 力を受けた場合のモデルとして，最も簡単な両端ピン支 持の円弧アーチを設定し，局部的な不安定現象をも解析 対象とするために, 有限要素法を用いて数値解析を行う。 外力は前章で求めた体積変化量の正確な表示に基づくポ テンシャルを直接変分することにより求められており, 静水圧型分布力の評価を極めて簡単に行い得ることが示 され，併わせてこの外王の変形依存性が系の弾性安定限 界に及ぼす影響についての検討が加えられる。

3-1 有限要素法による基礎式の定式化

ここでは，前章で求められた静水圧型の外圧に対する ポテンシャルの表示に基づいて，通常のはり要素による 有限要素法を用いて離散化する。

はり要素の変位，座標の規約はFig. 3-1 に示すとお りであり，通常扱われているように，面内変位 $u$ につ いては 1 次, 面外変位 $w$ については 3 次の代数内挿関 数を用いる。こうした規約に基づいて，ひずみ一変位関 係式は次式で表される。

$$
\begin{aligned}
& \varepsilon=d u / d s+\left((d u / d s)^{2}+(d w / d s)^{2}\right\} / 2 \\
& \varkappa=d^{2} w / d s^{2}+(d u / d s)\left(d^{2} w / d s^{2}\right)
\end{aligned}
$$

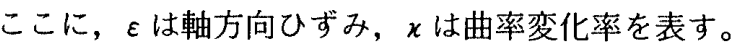
一要素あたりのひずみエネルギー $U^{e}$ は, 有限要素法の 通常の手続に従って次式のように求められる。

$$
U^{e}=H_{i j}^{e} d_{i}^{e} d_{j}^{e}+H_{i j k}^{e} d_{i}^{e} d_{j}^{e} d_{k}^{e}+H_{i j k l}^{e} d_{i}^{e} d_{j}^{e} d_{k}^{e} d_{l}^{e}
$$

ここに, $H_{i j}^{e}, H_{i j k}^{e}, H_{i j k l}^{e}$ は, 要素の節点変位ベクトル $d_{i}^{e}$ の並びに応じて作成される，1次，2 次，3 次のひず

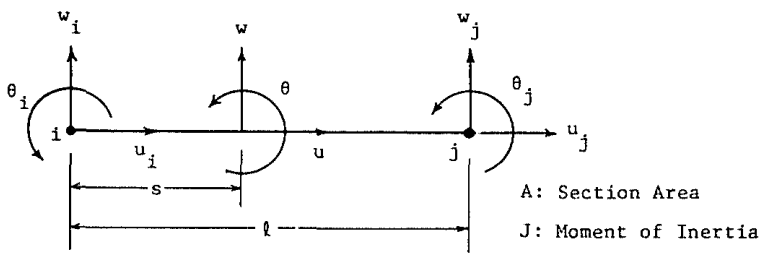

Fig. 3-1 Beam Element 
みエネルギーに対応する係数マトリクスである。なお， ここで下添字 $i, j, k, l$ 等に関しては, 総和規約を適 用するものとし, 以下特に断わらぬ限り,この約束に従 うものとする。

静水圧型外力の一要素あたりになす外力仕事 $W^{e}$ を, （2-8）式に基づいて評価すれば次式を得る的路2。 $W^{e}=\Lambda\left(\Delta E_{i j}^{e} d_{i}^{e} d_{j}^{e}+P_{i}^{e} d_{i}^{e}\right)$

ここに, $\Lambda$ は静水圧型外力の単位面積あたりの荷重を 表し， $\Delta$ は，これが0の時定方向型外力を，また，1の 時静水压型外力, すなわち法線方向変形依存型外力を表 す便宜的な指標である。また， $P_{i}^{e}$ は通常の扱いでの等 価節点力を表し， $E_{i j}^{e}$ は，外力の変形依存性を表す係数 マトリクスで,これらはそれぞれ次式のように表される。 $\left\{P_{i}^{e}\right\}^{T}=b\left[0, l / 2, l^{2} / 12,0, l / 2,-l^{2} / 12\right] \cdots \cdots(3-4)$

$$
\left[E_{i j}^{e}\right]=b\left[\begin{array}{cccccc}
0 & 0 & -l / 12 & 0 & -1 / 2 & l / 12 \\
& 0 & 0 & 1 / 2 & 0 & 0 \\
& & 0 & l / 12 & 0 & 0 \\
& \text { sym. } & & 0 & 0 & -l / 12 \\
& & & & 0 & 0 \\
& & & & & 0
\end{array}\right]
$$

ここに，bははり要素の幅，lは同じく長さを表す。

(3-5) 式で表現されているマトリクス $E_{i j}^{e}$ の非零の要 素の位置は, 線形要素剛性マトリクスの非零の要素の位 置とすべてずれており，変形依存型外力の持つ特性を示 すものである。(3-2) 式および（3-3）式で表される要 素のひずみエネルギーと外力仕事の表現を，座標変換を 通して全体座標系での表示とし，これを構造全体で重ね 合わせて得られる全ポテンシャルエネルギーを，節点変 位ベクトルで停留させることにより，つり合式として次 式を得る。

$$
\left(K_{i j}-\Delta \Lambda E_{i j}\right) d_{j}+K_{i j k} d_{j} d_{k}+K_{i j k l} d_{j} d_{k} d_{l}=\Lambda P_{i}
$$

この表現から判るとおり， $\Delta=1$ ，すなわち外力の変 形依存性を考慮する場合には，つり合式の表示中に，変 位 $d_{i}$ に関する非線形項はもとより，荷重パラメーター $\Lambda$ に関しても， $\Lambda d_{i}$ の項を含んでおり，荷重パラメ一 ターをも未知パラメーターと考えれば，それ自身，すで に非線形となる項を含んでいる。

（3-6）式を変位に関して線形化した，いわゆる線形つ り合式は次式で表される。

$$
\left(K_{i j}-\Delta \Lambda E_{i j}\right) d_{j}=\Lambda P_{i}
$$

この式から判るとおり，左辺の係数マトリクスは，各荷 重值に応じて漸次変化するもので，通常の意味での線形 解は存在しない。したがって，物理的考察により，(3-7) 式左辺第 2 項の非線形項の影響が無視できると判断でき る場合 (具体的には，線形膜解で十分近似できる場合等) 以外は, この種の問題には, 安定解析の手法としての線

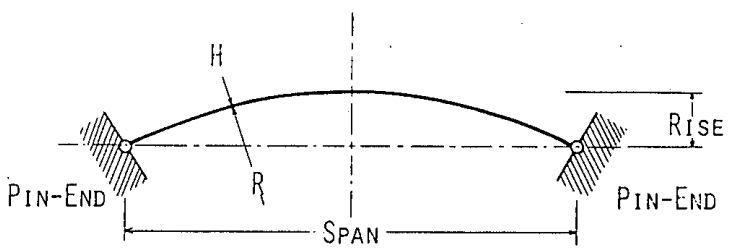

Fig. 3-2 Circular Arch

形固有値問題としての扱い方は，本来，適用できない。 3-2 数值解析

数値解析に用いたモデルは，Fig. 3-2 に示すような両 端ピン支持の円弧アーチであり，はり要素による分割を 20 の均等分割とし，対称変形を追跡する際には，対称 条件を設け，都合 10 分割で解析を実行した。

なお，(3-6）式で表される非線形代数方程式の数值解 析には，帯行列を用いた弧長法付绿が用いられており， さらに分岐点を求める手法については，通常の行列式を チェックする方法によっているが，分岐点近傍における 分岐方向の探索には, 普通よく用いられる固有値解析に よる方法，あるいは摂動的な手法 ${ }^{12}$ によらず，零固有值 を持つマトリクスの性質を利用した簡便な方法付绿が用 いられている。

数值解析は, 定方向外圧亡変形依存型外珐が系の安定 性に及ぼす影響を把握するために，円弧アーチの形状を 次に示すように変化させて行った。

荷重：定方向型外圧, 静水圧型外圧

形状：H/R=1/50,1/100,1/200

Rise/Span $=0.5 / 10,1 / 10,2 / 10,3 / 10$, $4 / 10,5 / 10$

ここでは，紙面の都合から，Rise/Span=2/10，3/10， 4/10，5/10の場合は割愛し，残りの 6 ケースについて 結果を示す。文献 18) にすべての結果を揭載している。 Fig. 3-3-1 Fig. 3-4-3にそれぞれの場合のつり合曲線 の全貌と分岐点付近のつり合曲線の詳細を示す。各図と も，実線で示すつり合曲線は定方向型の外圧による場合 を示し，破線は静水圧型の外玨による場合を示す。又， 詳細図中の一点鎖線は; Timoshenko と Gere ${ }^{13)}$ による 線形膜解からの固有値問題として得られる古典的座屈荷 重值を示しているが，これは次式から求められるもので ある。

$$
P_{c r}=\frac{E J}{R^{3}}\left(\frac{4 \pi^{2}}{\phi^{2}}-1\right)
$$

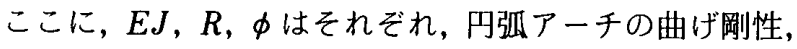
半径, 全開角を表す。また, Fig. 3-3-1 は, $H / R=0.02$, Rise/Span =0.5/10 の場合であるが，ここでは，飛移 点に致るまでのメインパス上に分岐点は存在しなかっ た。同図中に $P_{c r}$ とあるのは, 上述の Timoshenko と Gereによる值を示す。

3-3 解析結果の考察 

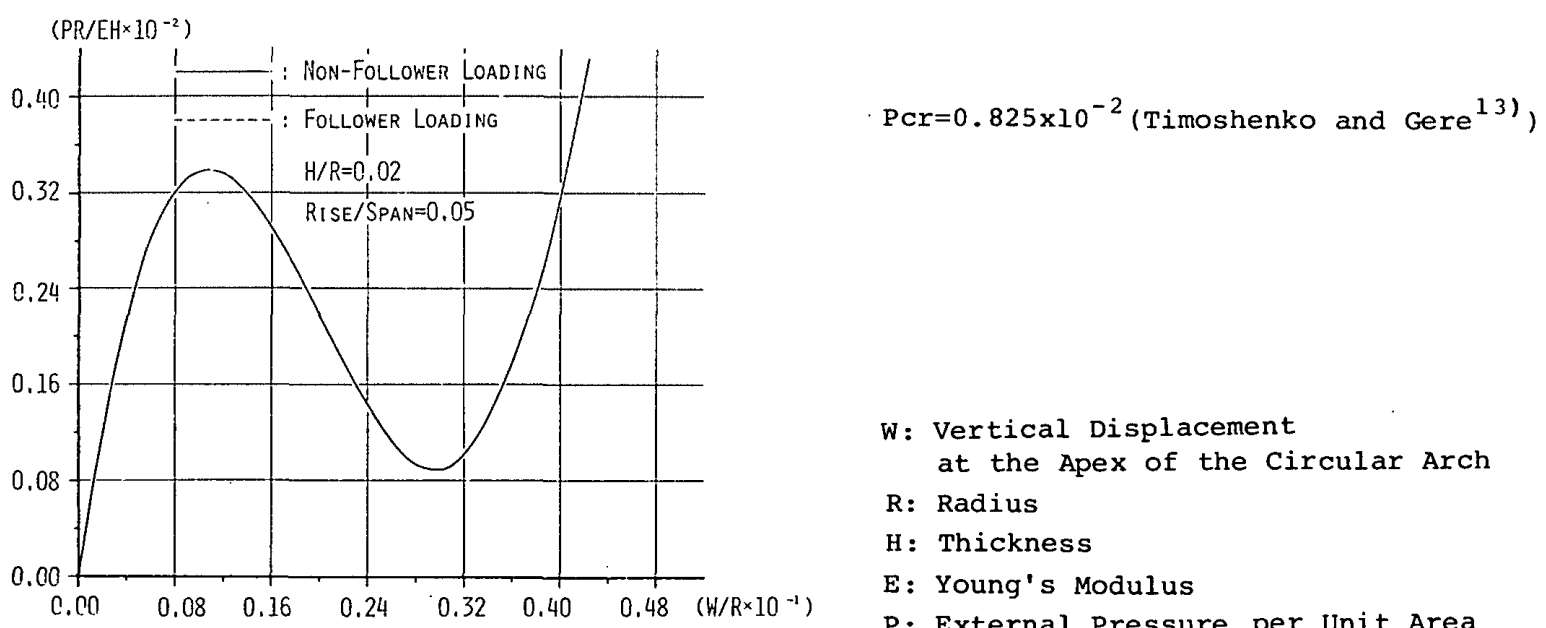

W: Vertical Displacement

at the Apex of the Circular Arch

R: Radius

H: Thickness

E: Young's Modulus

P: External Pressure per Unit Area

Fig. 3-3-1 Equilibrium Path

$\left(\mathrm{PP} / \mathrm{EH} \times 10^{2}\right)$

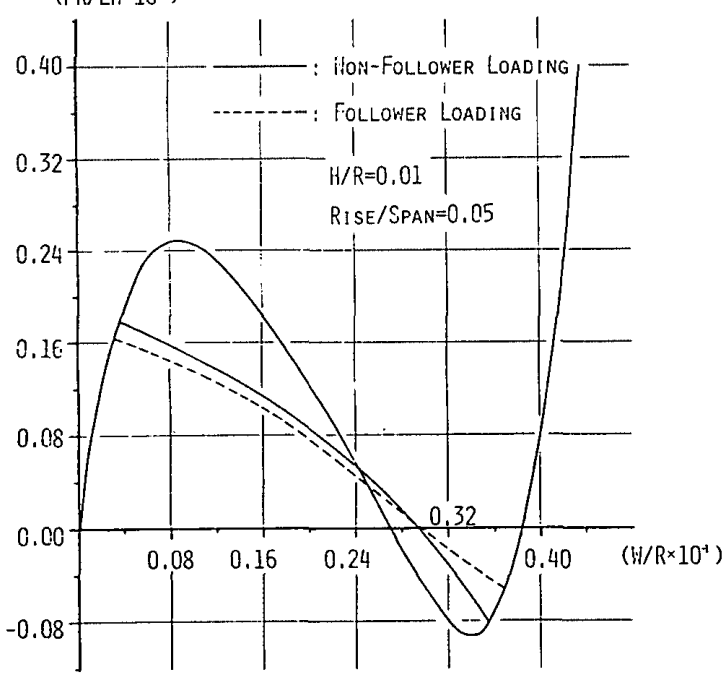

Fig. 3-3-2 a Equilibrium Path

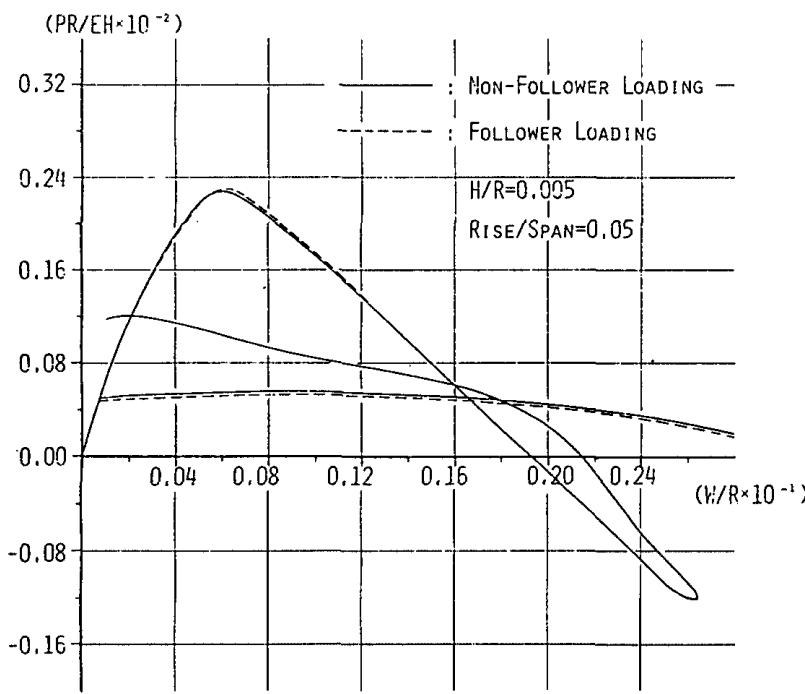

Fig. 3-3-3 a Equilibrium Path

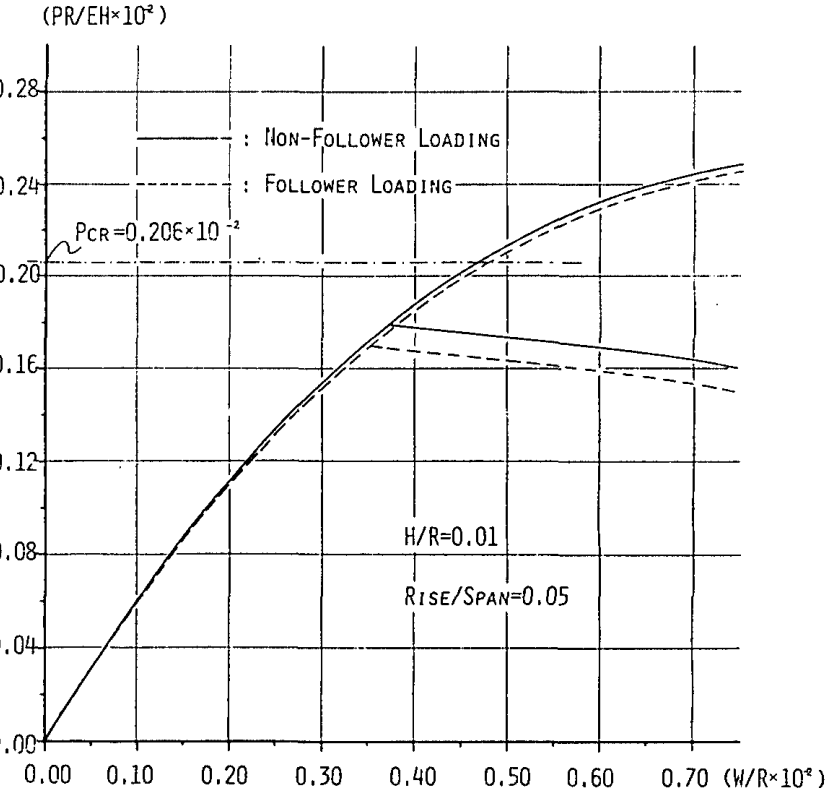

Fig. 3-3-2 b Equilibrium Path

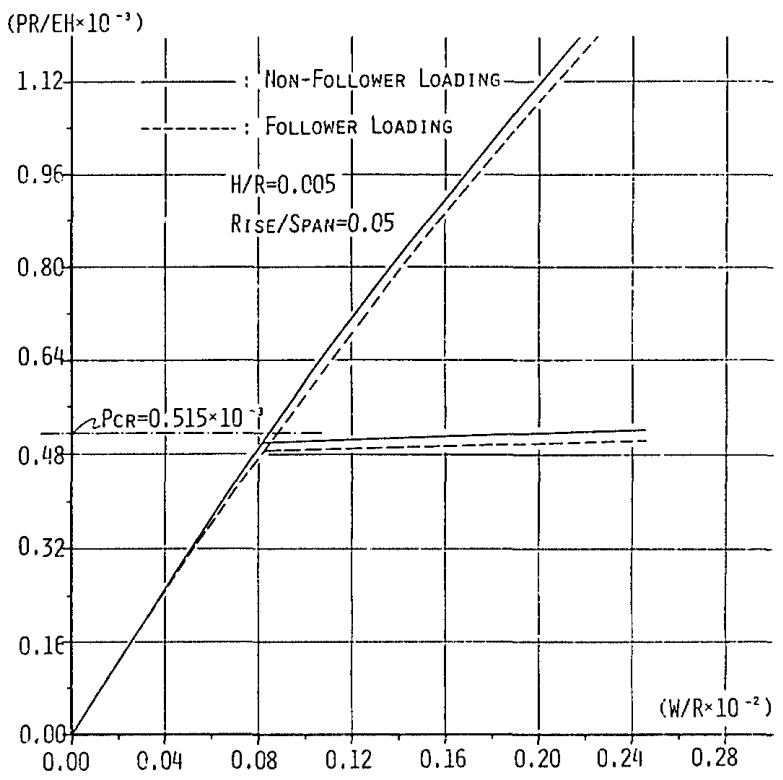

Fig. 3-3-3 b Equilibrium Path 


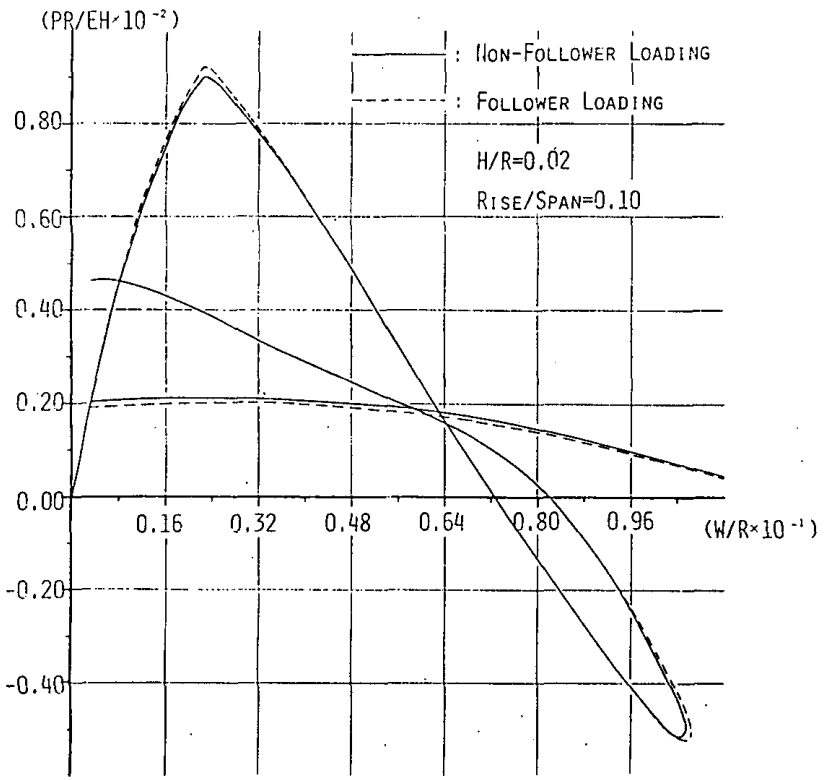

Fig. 3-4-1 a Equilibrium Path

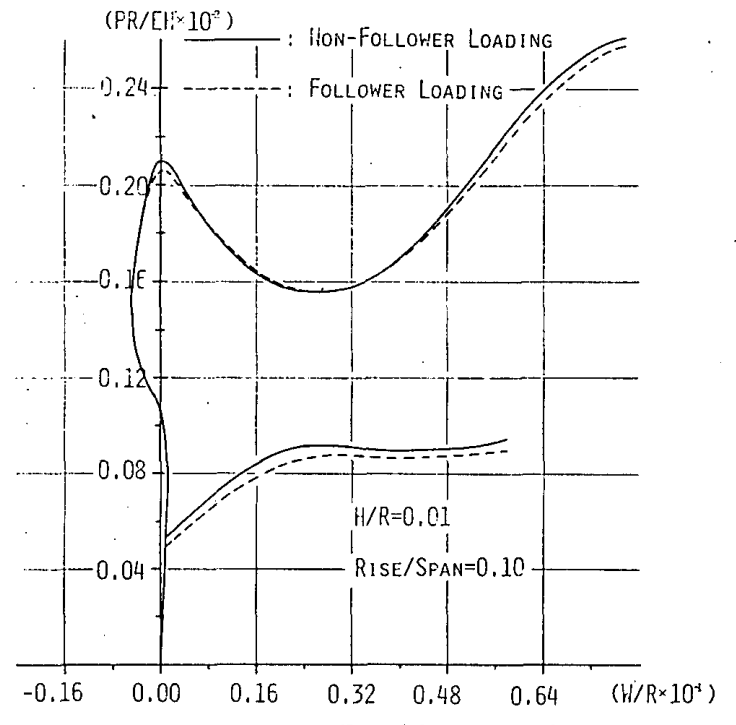

Fig. 3-4-2 a Equilibrium Path

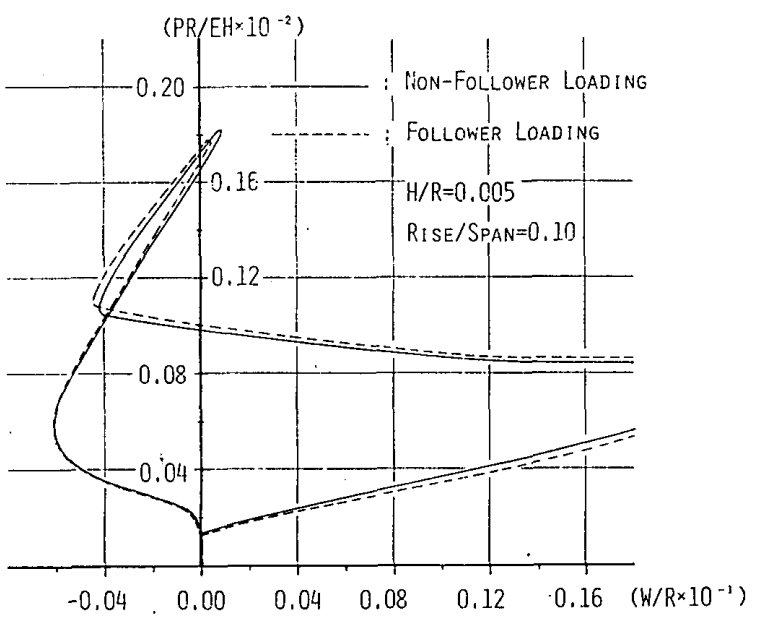

Fig. 3-4-3 a Equilibrium Path

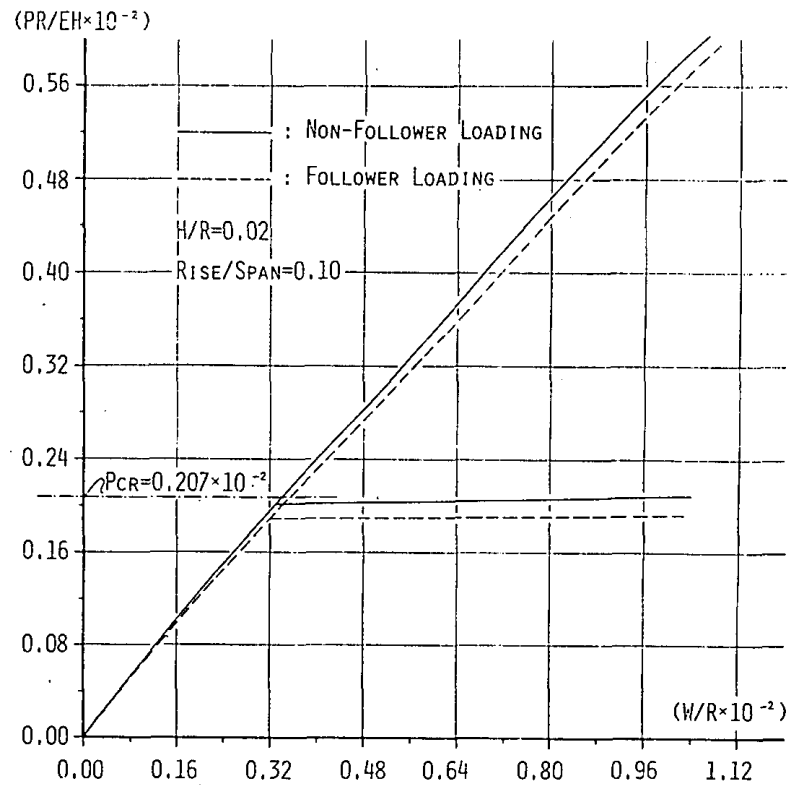

Fig. 3-4-1 b Equilibrium Path
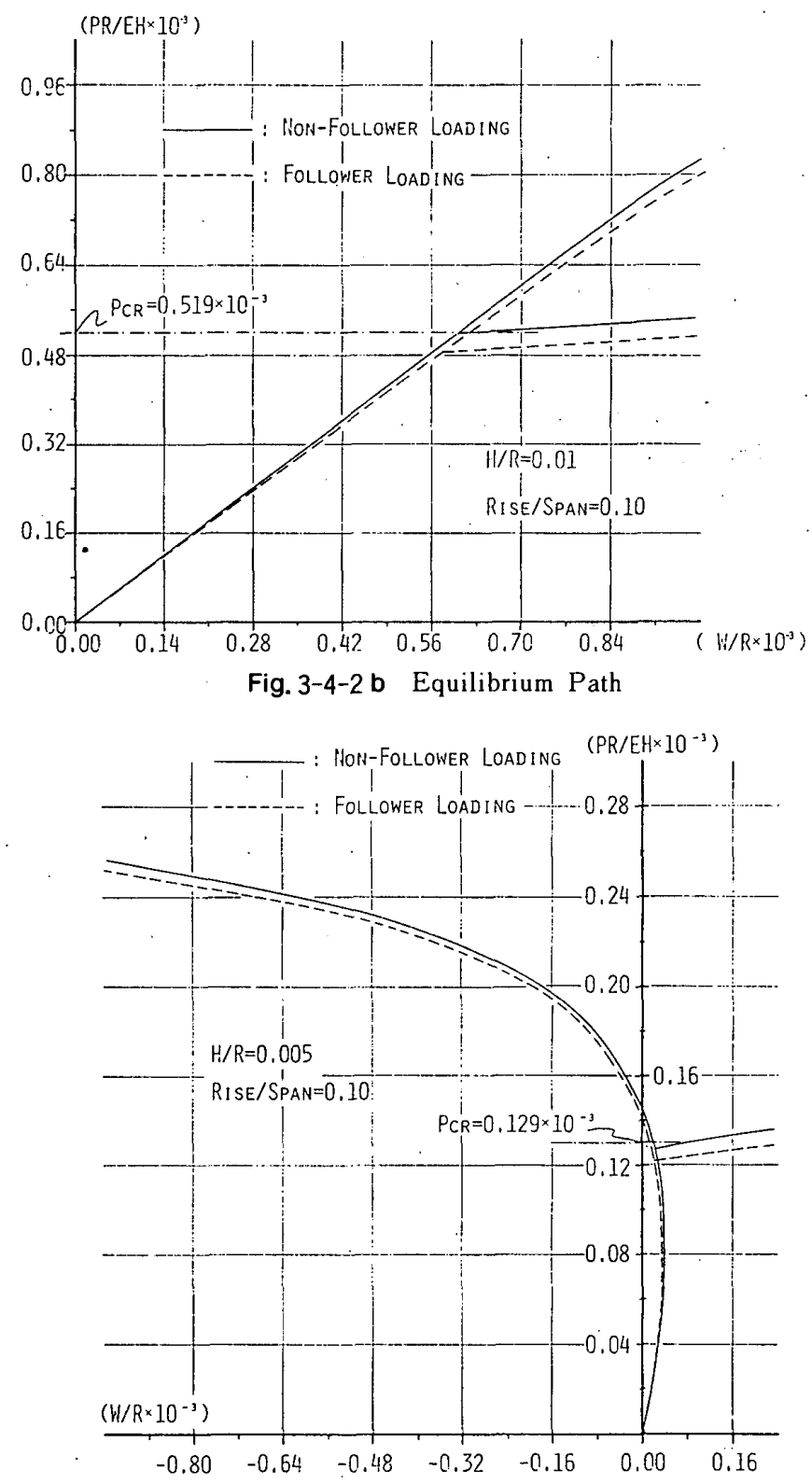

Fig. 3-4-3 b Equilibrium Path 
以上の解析の結果から, 定方向型と静水圧型の外圧が 円弧アーチの弾性安定性状に及ぼす影響について次のよ うなことがいえる。

まず，メインパスについては，各形状を通じて，両者 の外圧形式の相違によって, $H / R$ が小さく, Rise/Span が大きいほど，すなわち，ア一チの部材成が小さく， ライズが大きいほよ゙，両者の間に差異を生ずるようにな る。また，両外圧形式を問わず，Rise/Span が大きく なるにつれて，飛移点が分岐点と比べて極めて高い荷重 レベルに位置するようになり，Rise/Span の大きいアー チでは，分岐点のみに焦点を合わせた議論で実用的には 十分である。また，Fig. 3-4に見られるようなメインパ ス上の複数の極限点は, 系が小規模な部分飛移座屈を生 起しつつ,つり合形状を変化させていくことを示すもの で，ライズの大きいアーチに起こるものである。

分岐点は, 定方向型外圧と比べて, 静水圧型外圧の場 合の方が，その荷重レベルにおいて，ここで扱ったすべ てのヶースについて下回っており，その低下の度合は $H / R$ が小さく, Rise/Span が大きいほど大きくでてい る。これは，実用的には，外力の変形依存性を無視する と限界圧力を危険側に見積ることを示すもので，注意を 要する場合があり得ることを意味している。

次に，分岐点付近における円弧アーチの挙動について 見てみるとここで扱った形状の中では， $H / R=1 / 100$, Rise/Span $=0.5 / 10$ の場合を除いて，他の場合ではす べて安定分岐点となっていることが，つり合曲線から判 断できる。この安定分岐点においては，系は，分岐点に 対応する荷重レベルからのわずかな荷重増加に対して， 理論的にはメインパス以外に，分岐点近傍にもうひとつ のつり合状態を持ち，そのため円弧ア一チは，大きな変 形を生ずることなく，単にそれまでとは別の様式で変形
を進行させるに過ぎないことを意味している。しかし， 例えばFig. 3-3-3ゃFig. 3-4-1に示されている分岐パ スは, 分岐点での荷重レベルよりもわずかに高い荷重レ ベルにおいて,分岐パス上での飛移点を持つものであり， 安定分岐とはいえ, 現象的には通常の不安定分岐点とそ れほど異なるものではない。また, 他の形状の場合でも, 分岐点通過後に, 系がその変形能を大きく変化させるこ とは事実であり，実際的にはやはり不安定点と考えるべ きである。なお, 微小振動法を用いたつり合点の安定判 別については付録 5 に詳述している。 $H / R$ および Rise/Span のそれぞれの値に対する弾性安定限界荷重 について, 前述の Timoshenko の値と比較しつつ, 定 方向型外力, 静水圧型外力について, Table 2 にそれら の数値を示す。

4. ノーマルモード法による円弧アーチの弾性安定解析 各種の構造物の弾性安定を解析する際, 自由振動モ一 ドを用いた低自由度での安定解析が行われることが多 い。これは普通, ノーマルモード法と呼ばれており，対 象とする系の自由度を重み付き固有関数の線形和で近似 するものである。通常, 採用するモードは低次のモード から順次採用項数を上げてゆくために，特に系が局部的 な変形を伴うような不安定挙動を示す際には，これを低 次のモードだけで近似することが困難であるため，良好 な精度を得るためには採用モードを増やす必要が生ず る。一方 3 章で扱った有限要素法の場合には, 変位場が スプライン関数として与えられているので, 局所的な変 形挙動に対応できるという長所を持つ一方, 系全体が滑 らかに変形する場合にはそれを正しく表現するためのス プライン関数群を扱わざるを得ず，所要の精度を保持し ようとすれば自由度は大きくなる。このように有限要素 法とノーマルモード法は互いに相補的であると言える。

Table 2 Comparison of Critical Loads

\begin{tabular}{|c|c|c|c|c|c|c|}
\hline $\begin{array}{c}\text { Rise/Span } \\
\mathrm{H} / \mathrm{R}\end{array}$ & $0.5 / 10$ & $1 / 10$ & $2 / 10$ & $3 / 10$ & $4 / 10$ & $5 / 10$ \\
\hline \multirow{3}{*}{$1 / 50$} & & $2.07 \times 10^{-3}$ & $5.34 \times 10^{-4}$ & $2.48 \times 10^{-4}$ & $1.47 \times 10^{-4}$ & $1.00 \times 10^{-4}$ \\
& & $2.04 \times 10^{-3}$ & $5.59 \times 10^{-4}$ & $2.78 \times 10^{-4}$ & $1.70 \times 10^{-4}$ & $1.18 \times 10^{-4}$ \\
& & $1.92 \times 10^{-3}$ & $4.97 \times 10^{-4}$ & $2.35 \times 10^{-4}$ & $1.43 \times 10^{-4}$ & $8.36 \times 10^{-4}$ \\
\hline \multirow{3}{*}{$1 / 100$} & $2.06 \times 10^{-3}$ & $5.19 \times 10^{-4}$ & $1.33 \times 10^{-4}$ & $6.20 \times 10^{-5}$ & $3.68 \times 10^{-5}$ & $2.50 \times 10^{-5}$ \\
& $1.78 \times 10^{-3}$ & $5.19 \times 10^{-4}$ & $1.42 \times 10^{-4}$ & $7.10 \times 10^{-5}$ & $4.64 \times 10^{-5}$ & $2.84 \times 10^{-5}$ \\
& $1.70 \times 10^{-3}$ & $4.80 \times 10^{-4}$ & $1.21 \times 10^{-4}$ & $5.44 \times 10^{-5}$ & $3.60 \times 10^{-5}$ & $1.97 \times 10^{-5}$ \\
\hline \multirow{3}{*}{$1 / 200$} & $5.15 \times 10^{-4}$ & $1.29 \times 10^{-4}$ & $3.34 \times 10^{-5}$ & $1.55 \times 10^{-5}$ & $9.20 \times 10^{-6}$ & $6.25 \times 10^{-6}$ \\
& $4.96 \times 10^{-4}$ & $1.27 \times 10^{-4}$ & $3.84 \times 10^{-5}$ & $1.80 \times 10^{-5}$ & $1.19 \times 10^{-6}$ & $6.90 \times 10^{-6}$ \\
& $4.80 \times 10^{-4}$ & $1.22 \times 10^{-4}$ & $3.24 \times 10^{-5}$ & $1.47 \times 10^{-5}$ & $8.76 \times 10^{-6}$ & $4.56 \times 10^{-6}$ \\
\hline
\end{tabular}

Upper Row: Timoshenko's Solution ${ }^{13)}$

Middle Row: Non-Follower Load (Present Analysis) Lower Row: Follower Load (Present Analysis) 
本章では前章の冈弧アーチを対象として, 定方向外圧, 静水王型外王を受けた場合の安定解析に，ノーマルモー ド法を用いた場合について記述する。分岐型の弾性安定 限界荷重については, 前章では有限要素法により約 60 自由度で求められているのに対し，ノーマルモード法に よれば, 対称モード, 非対称モードそれぞれ 2 波の合計 . 4 自由度で, 両外生形式の場合とも十分な精度で求めら れることが, 解析の結果により示される。

\section{4-1，基礎式の誘導}

Fig. 4-1 に示すようなモデルを考える。以下に, 全ポ テンシャルエネルギーの最小原理に基づいて基礎式を誘 導する。まず,ひずみ一変位関係式は次式で与えられる。

$$
\begin{aligned}
& \varepsilon=u^{\prime}-w+\left(w^{\prime}+u\right)^{2} / 2 \\
& R x=w^{\prime \prime}+u^{\prime}
\end{aligned}
$$

ここで, $\bar{u}=R u, \bar{w}=R w,()^{\prime}=d() / d \varphi$ としており, $\varepsilon$ はアーチの軸ひずみ， $x$ は曲率変化率を表す。

次に, 系のひずみエネルギー $U$, 外力のなす仕事量 $W$ は, 次式のように表される。

$$
\begin{aligned}
& U=E R b h\left\langle\varepsilon^{2}+\alpha R^{2} x^{2}\right\rangle / 2 \\
& W=q R^{2}\left\langle w+\Delta\left(w u^{\prime}-u w^{\prime}\right) / 2-\Delta\left(u^{2}+w^{2}\right) / 2\right\rangle
\end{aligned}
$$

ここに，矩形断面の材を想定し， $\alpha=h^{2} / 12 R^{2}$ とし, $\langle A\rangle=\int_{-\varphi_{0} / 2}^{\varphi_{0} / 2} A(\varphi) d \varphi$ であり, $\Delta$ は前章と同様, $\Delta=0$ の 時定方向外力, $\Delta=1$ の時静水圧型外力を表す便宜的指 標である。この表示に, (4-1) 式を代入し, 全ポテンシャ ルエネルギー最小原理を用いてつり合式を求めると次式 を得る。

$$
\begin{aligned}
& u^{\prime \prime}-w^{\prime}+\alpha\left(w^{\prime \prime \prime}+u^{\prime \prime}\right)+w^{\prime} w^{\prime \prime}+w w^{\prime}+u w^{\prime \prime} \\
& +u w-\left(w^{\prime}+u\right)^{3} / 2-\lambda \alpha \Delta\left(w^{\prime}+u\right)=0 \\
& u^{\prime}-w-\alpha\left(w^{i v}+u^{\prime \prime \prime}\right)+u^{\prime \prime} w^{\prime}-\left(w^{\prime}\right)^{2} / 2+u^{2} / 2 \\
& +u u^{\prime \prime}+u^{\prime} w^{\prime \prime}-w w^{\prime \prime}+\left(u^{\prime}\right)^{2}-u^{\prime} w \\
& \quad+3\left(w^{\prime}+u\right)^{2}\left(w^{\prime \prime}+u^{\prime}\right) / 2+\lambda \alpha\left\{1+\Delta\left(u^{\prime}-w\right)\right\}=0
\end{aligned}
$$

ここに, $\lambda$ は荷重パラメーターで, $q=\lambda\left(E J / R^{3}\right)$ である

( $J$ : 断面 2 次モーメント)。

\section{4-2 ノーマルモード法の適用}

ノーマルモード法は, 系の自由振動モードを用いて, 基礎式の近似解を求めようとするもので，各モードは互 いに直交しており，かつ問題の境界条件を完全に満足し

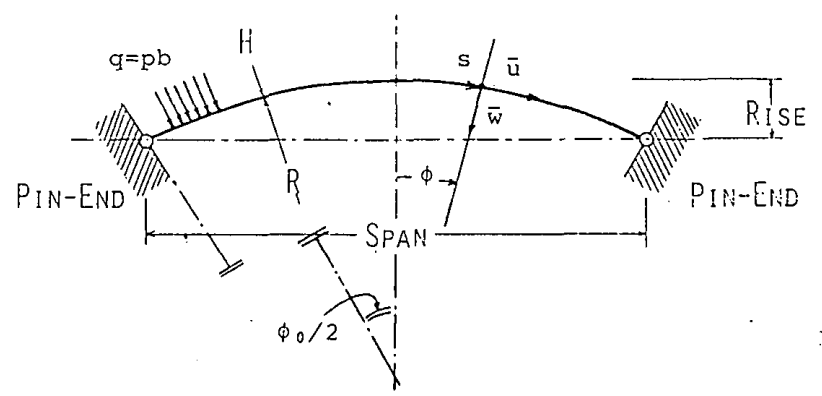

Fig. 4-1 Circular Arch
ている。したがって，境界条件を満たす任意の直交関数 を仮定関数として用いた場合の扱いと本質的にまったく 同一のものであり，その意味で，Galerkin 法に属する 手法のひとつであるということができる。ここでは，後 の解析のための基礎式を誘導する。

今, $u(\varphi)$ と $w(\varphi)$ を次式の形式で仮定する。 $u(\varphi)=a_{i} G_{i}(\varphi), \quad w(\varphi)=b_{i} H_{i}(\varphi)$

ここで, 表現の約束として, 総和規約を用いている。また, $G_{i}(\varphi), H_{i}(\varphi)$ は, それぞれ問題の境界条件,

$\varphi= \pm \varphi_{0} / 2: u=w=w^{\prime \prime}+u^{\prime}=0 \cdots$

を満足する関数であるものとする。この仮定関数を用い

て，(4-3）式に Galerkin 法を適用すると次式を得る。

$$
\begin{aligned}
& \left\langleG _ { i } \left\{ L_{1}(u, w)+N_{11}(u, w)+N_{12}(u, w)\right.\right. \\
& \left.\quad+\lambda \alpha F_{1}(u, w)\right\rangle=0 \\
& \left\langleH _ { i } \left\{ L_{2}(u, w)+N_{21}(u, w)+N_{22}(u, w)\right.\right. \\
& \quad+\lambda \alpha F_{2}(u, w)|\rangle=0
\end{aligned}
$$

$$
\text { ここに, } \begin{aligned}
L_{1}(u, w)= & (1+\alpha) G_{j}^{\prime \prime} a_{j}+\left(-H_{j}^{\prime}+\alpha H_{j}^{\prime \prime}\right) b_{j} \\
L_{2}(u, w)= & \left(G_{j}^{\prime}-\alpha G_{j}^{\prime \prime}\right) a_{j}+\left(-H_{j}-\alpha H_{j}^{\prime \prime}\right) b_{j} \\
N_{11}(u, w)= & \left(H_{j}^{\prime} H_{k}^{\prime \prime}+H_{j} H_{k}^{\prime}\right) b_{j} b_{k} \\
& +G_{j}\left(H_{k}^{\prime \prime}+H_{k}\right) a_{j} b_{k} \\
N_{21}(u, w)= & \left(-H_{j}^{\prime} H_{k}^{\prime} / 2-H_{j} H_{k}^{\prime \prime}\right) b_{j} b_{k} \\
& +\left(G_{j}^{\prime \prime} H_{k}^{\prime}+G_{j}^{\prime} H_{k}^{\prime \prime}-G_{j}^{\prime} H_{k}\right) a_{j} b_{k} \\
& +\left(G_{j} G_{k} / 2+G_{j} G_{k}^{\prime \prime}+G_{j}^{\prime} G_{k}^{\prime \prime}\right) a_{j} a_{k} \\
N_{12}(u, w)= & -(1 / 2)\left(H_{j}^{\prime} H_{k}^{\prime} H_{l}^{\prime} b_{j} b_{k} b_{l}\right. \\
& +3 G_{j} H_{k}^{\prime} H_{l}^{\prime} a_{j} b_{k} b_{l} \\
& +3 G_{j} G_{k} H_{l}^{\prime} a_{j} a_{k} a_{l} \\
& \left.+G_{j} G_{k} G_{l} a_{j} a_{k} a_{l}\right)
\end{aligned}
$$

$N_{22}(u, w)=(3 / 2)\left(G_{j}^{\prime} H_{k}^{\prime} H_{l}^{\prime} a_{j} b_{k} b_{l}\right.$

$$
+2 G_{j} G_{k}^{\prime} H_{l}^{\prime} a_{j} a_{k} b_{l}
$$$$
+G_{j}^{\prime} G_{k} G_{l} a_{j} a_{k} a_{l}
$$$$
+H_{j}^{\prime} H_{k}^{\prime} H_{l}^{\prime \prime} b_{j} b_{k} b_{l}+2 G_{j} H_{k}^{\prime} H_{l}^{\prime \prime} a_{j} b_{k} b_{l}
$$$$
\left.+G_{j} G_{k} H_{l}^{\prime \prime} a_{j} a_{k} a_{l}\right)
$$

$F_{1}(u, w)=-\Delta\left(H_{j}^{\prime} b_{j}+G_{j} a_{j}\right)$

$F_{2}(u, w)=1+\Delta\left(G_{j}^{\prime} a_{j}-H_{j} b_{j}\right)$

(4-6) 式の係数を整理すれば次式のつり合式を得る。

$$
\begin{aligned}
& \left(K_{i j}+\Delta \lambda \alpha E_{i j}\right) x_{j}+K_{i j k} x_{j} x_{k}+K_{i j k l} x_{j} x_{k} x_{l} \\
& \quad+\lambda \alpha P_{i}=0 \ldots \ldots \ldots \ldots \ldots \ldots \ldots \ldots \ldots \ldots \ldots \ldots \ldots \ldots \ldots \ldots \ldots \ldots \ldots \ldots \ldots
\end{aligned}
$$

ここで， $x_{i}$ は $a_{i}$ と $b_{i}$ とを並べたベクトルであり，各 係数は, (4-6) 式の積分を実行して得られるものである。 4-3 自由振動解析

前節で仮定関数として表現した $H_{i}(\varphi), G_{i}(\varphi)$ として, 自由振動モードを採用する。この自由振動モードの表現 の方法には，なんらかの近似的な手法により離散的に表 現する手法と，解析的に表現する方法が考えられる。前 者の離散的な方法とは, 例えば通常の Galerkin 法や FEM などにより, 系の自由振動方程式をなんらかの仮 
定関数を用いて離散化し、これを固有値問題として解い た上で固有モードをそれぞれの仮定関数に応じた重みの 並びで表現し，これを基礎式に用いるものである。この 方法は一般に扱いが容易である反面，あくまでも近似的 に固有モードを表現しているにすぎず，仮定調波不足に 起因する誤差を避けることができない。これに対して， 後者の解析的な方法では，扱いは一般に容易でなくなる 反面，ひとたびそこに現れる超越方程式なり，非線形の 代数方程式が解かれてしまえば，その解により表現され る固有関数は完全に厳密なものとなり, 固有モードの表 現不足に由来する誤差は皆無となる。ここでは, 円弧ア一 于の特性方程式が, 高々 3 次の代数方程式となり,これ を厳密に解くことが比較的容易であることに着目し，後 者の方法を採用した。

円弧アーチの自由振動の線形方程式は，(4-3) 式で非 線項と荷重項を除き，慣性項を付加して，次式で表され る。

$$
\begin{aligned}
& \partial^{2} u / \partial \varphi^{2}-\partial w / \partial \varphi+\alpha\left(\partial^{3} w / \partial \varphi^{3}+\partial^{2} u / \partial \varphi^{2}\right) \\
& -\bar{k} \partial^{2} u / \partial t^{2}=0 \\
& \partial u / \partial \varphi-w-\alpha\left(\partial^{4} w / \partial \varphi^{4}+\partial^{3} u / \partial \varphi^{3}\right) \\
& -\bar{k} \partial^{2} w / \partial t^{2}=0
\end{aligned}
$$

ここに, $\bar{k}=\rho R^{2} / E$ であり, $\rho$ はアーチ部材の単位体積 あたりの質量を表す。 $u, w$ を次式で変数分離する。 $w(\varphi, t)=W(\varphi) e^{i \omega t}, u(\varphi, t)=U(\varphi) e^{i \omega t}$

これを, (4-8) 式に用いれば次式の常微分方程式を得る。

$$
\begin{aligned}
& d^{2} U / d \varphi^{2}-d W / d \varphi+\alpha\left(d^{3} W / d \varphi^{3}\right. \\
& \left.\quad+d^{2} U / d \varphi^{2}\right)+\bar{k} \omega^{2} U=0 \\
& d U / d \varphi-W-\alpha\left(d^{4} W / d \varphi^{4}+d^{3} U / d \varphi^{3}\right) \\
& \quad+\bar{k} \omega^{2} W=0
\end{aligned}
$$

ここで, $U(\varphi), W(\varphi)$ を次式のように置く。

$$
\left.\begin{array}{l}
U(\varphi)=A_{i} \sin n_{i} \varphi+B_{i} \cos n_{i} \varphi \\
W(\varphi)=\bar{A}_{i} \sin n_{i} \varphi+\bar{B}_{i} \cos n_{i} \varphi
\end{array}\right\}
$$

これを(4-10) 式に用いれば，次式の特性方程式を得る。

$$
n_{i}^{6}-(2+\alpha k) n_{i}^{4}-(k+\alpha k-1) n^{2}+k(\alpha k-1)=0
$$

ここに, $k=\bar{k} \omega^{2} / \alpha$ とする。これを満たす $n_{i}$ について, (4-11) 式は次式のように表される。

$$
\left.\begin{array}{l}
U(\varphi)=\sum_{i=1}^{3}\left(A_{i} \sin n_{i} \varphi+B_{i} \cos n_{i} \varphi\right) \\
W(\varphi)=\sum_{i=1}^{3} a_{i}\left(B_{i} \sin n_{i} \varphi-A_{i} \cos n_{i} \varphi\right)
\end{array}\right\}
$$

ここに， $a_{i}=\left\{\alpha k-(1+\alpha) n_{i}^{2} \mid / n_{i}\left(1+\alpha n_{i}^{2}\right)\right.$ とする。 ここで,簡単のために， $\varphi=0$ について対称な変形と逆 対称な変形とに分けて扱うことにする。すなわち, （i）対称変形 $: U_{s}(\varphi)=\sum_{i=1}^{3} A_{i} \sin n_{i} \varphi$

$$
W_{s}(\varphi)=\sum_{i=1}^{3}\left(-a_{i} A_{i}\right) \cos n_{i} \varphi
$$

(ii) 逆対称変形: $U_{a}(\varphi)=\sum_{i=1}^{3} B_{i} \cos n_{i} \varphi$

$$
W_{a}(\varphi)=\sum_{i=1}^{3} a_{i} B_{i} \sin n_{i} \varphi
$$

境界条件は，次式で表される。

$$
\varphi= \pm \varphi_{0} / 2: U=W=W^{\prime \prime}+U^{\prime}=0
$$

(4-14) 式をこれに用いれば，対称，逆対称の場合に対 応して次式の同次方程式系を得る。

(i) 対称変形

$$
\begin{gathered}
{\left[\begin{array}{cc}
-a_{1} \cos n_{1} \varphi_{0} / 2 & -a_{2} \cos n_{2} \varphi_{0} / 2 \\
\sin n_{1} \varphi_{0} / 2 & \sin n_{2} \varphi_{0} / 2 \\
n_{1}\left(1+n_{1} a_{1}\right) \cos n_{1} \varphi_{0} / 2 & n_{2}\left(1+n_{2} a_{2}\right) \cos n_{2} \varphi_{0} / 2 \\
-a_{3} \cos n_{3} \varphi_{0} / 2 \\
\sin n_{3} \varphi_{0} / 2 \\
n_{3}\left(1+n_{3} a_{3}\right) \cos n_{3} \varphi_{0} / 2
\end{array}\right] \cdot\left\{\begin{array}{l}
A_{1} \\
A_{2} \\
A_{3}
\end{array}\right\}=\{0\}}
\end{gathered}
$$

(ii) 逆対称変形

$$
\begin{gathered}
{\left[\begin{array}{cc}
a_{1} \sin n_{1} \varphi_{0} / 2 & a_{2} \sin n_{2} \varphi_{0} / 2 \\
\cos n_{1} \varphi_{0} / 2 & \cos n_{2} \varphi_{0} / 2 \\
-n_{1}\left(1+n_{1} a_{1}\right) \sin n_{1} \varphi_{0} / 2 & -n_{2}\left(1+n_{2} a_{2}\right) \sin n_{2} \varphi_{0} / 2 \\
a_{3} \sin n_{3} \varphi_{0} / 2 \\
\cos n_{3} \varphi_{0} / 2 \\
-n_{3}\left(1+n_{3} a_{3}\right) \sin n_{3} \varphi_{0} / 2
\end{array}\right] \cdot\left\{\begin{array}{l}
B_{1} \\
B_{2} \\
B_{3}
\end{array}\right\}=\{0\}}
\end{gathered}
$$

結局，(4-12）式と (4-16) 式あるいは (4-17) 式とを 同時に満足する $n_{i}$ と $k$ とのペアが系の自由振動モード を与えることになる。

このようにして得られた結果として, 無次元化された 振動数と細長比（アーチの弧長/断面 2 次半径）との関 係を, Fig. 4-2 に示し, 特定の細長比に対する系の固有 モードとその時の $k$ の值を, 1 次および 2 次について Fig. 4-3（図中, S.R. は細長比）に示す。

4-4 固有関数展開による非線形解析

本節では, 前節で求められた陽な形式の固有関数を用 いて, 円弧アーチの安定解析を行った結果を示す。数値 解析に用いたアーチの諸元は次の 3 ケースである。

$$
H / R=1 / 50,1 / 100,1 / 200 ; \text { Rise/Span }=1 / 10
$$

結果を,Fig. 4-4〜Fig. 4-6に示す。ここでの採用波数 は, 対称モード 2 波, 逆対称モード 2 波の合計 4 自由度 とした。図中，太い実線がこの時の定方向型外力による 結果を示し, 同じく破線が静水圧型外力による結果を示 す。細い実線と破線は，前章で示されたFEMによる 結果である。これらの結果から,メインパス上の変形と 荷重が進行したか所については, ここでのノーマルモー 


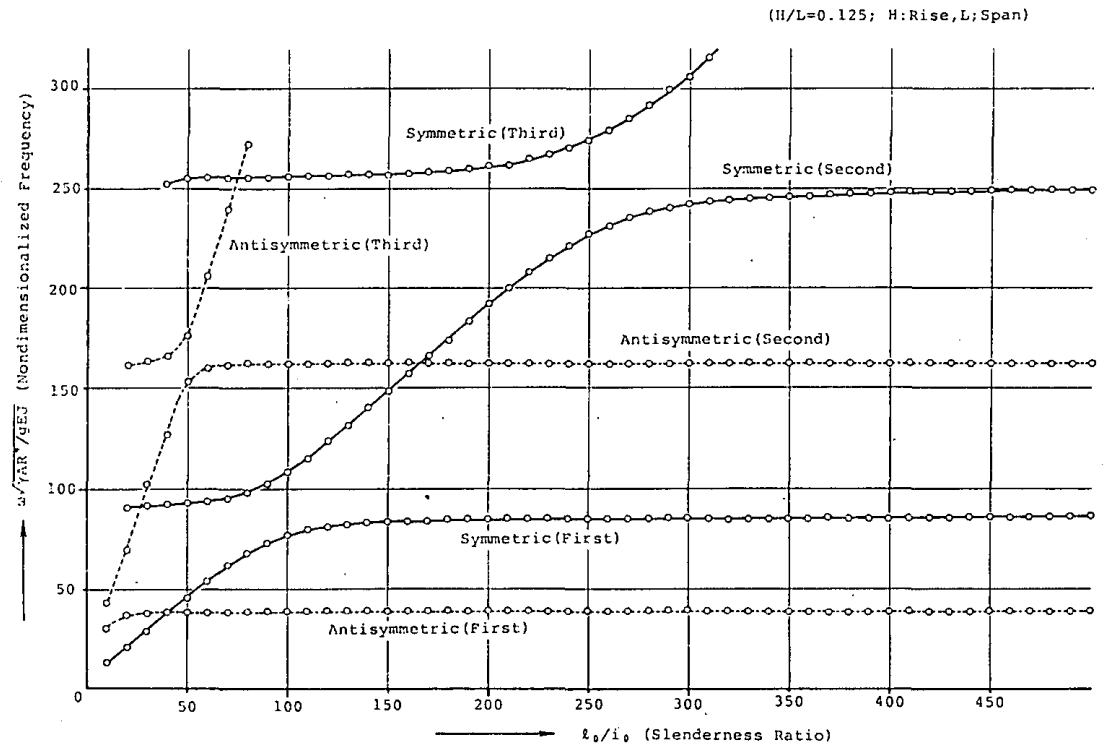

Fig. 4-2 Nondimensionalized Frequency versus Slenderness Ratio
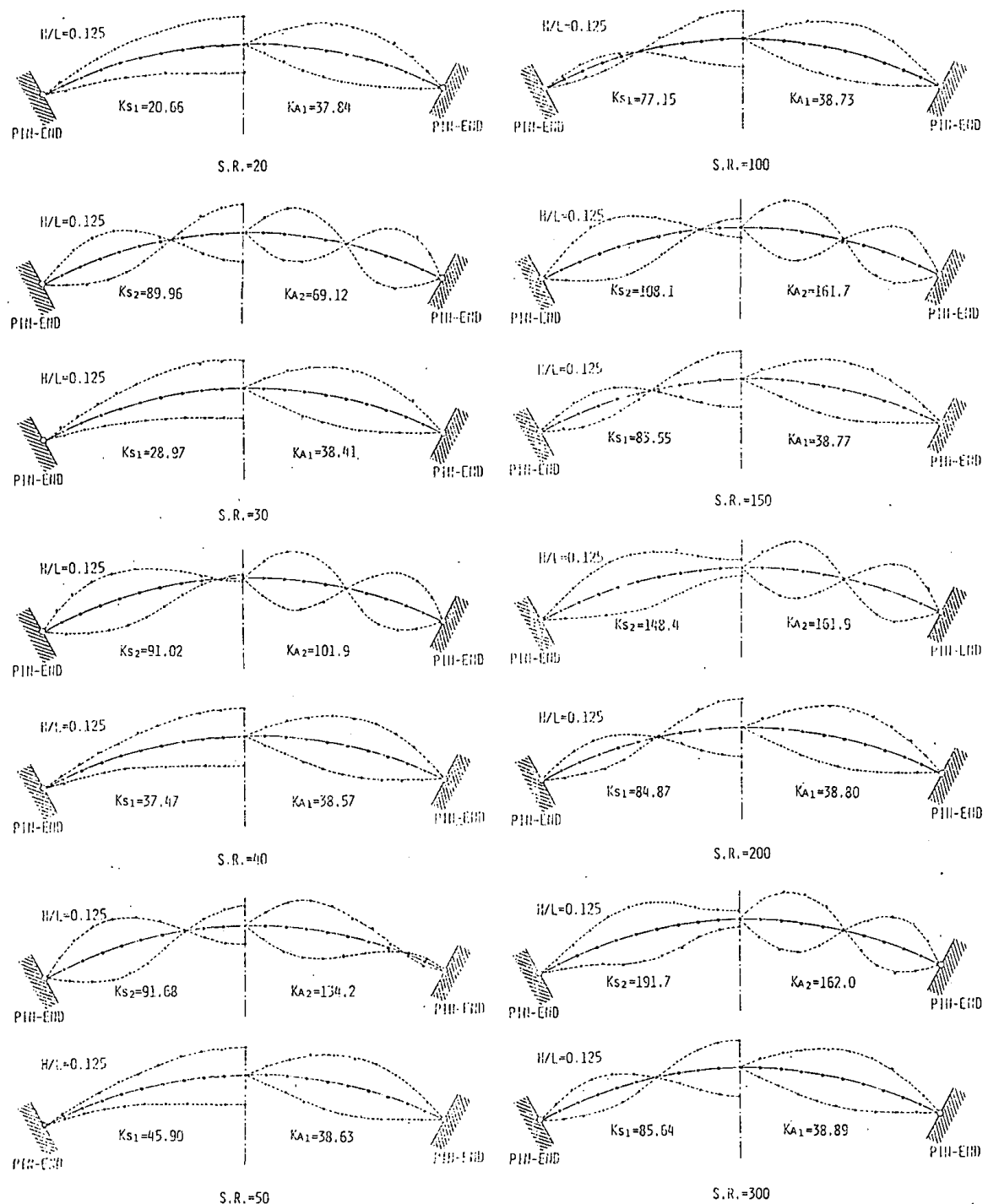

$S . R . * 50$

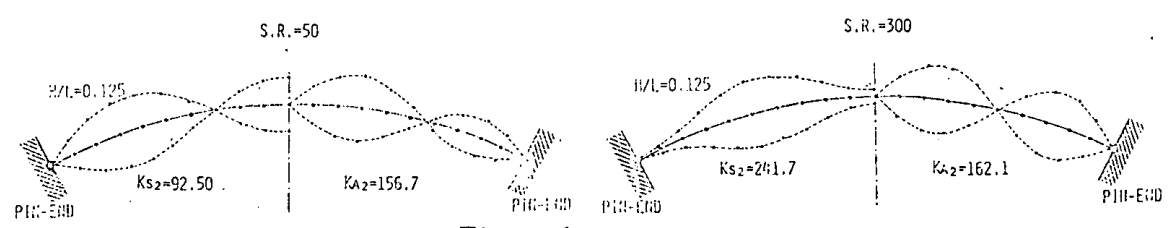

Fig. 4-3 Eigenvalues and Eigenmodes 


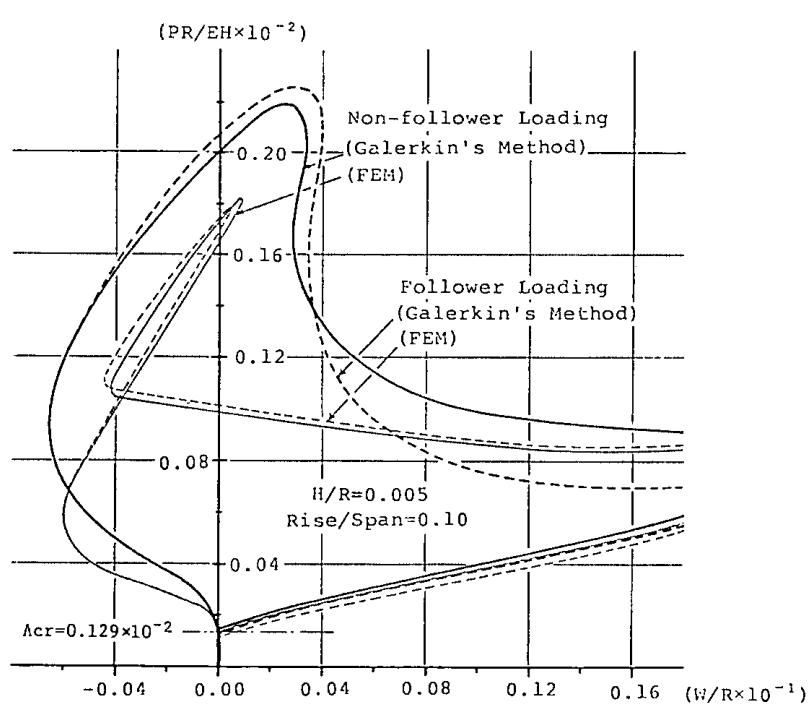

Fig. 4-4 Equilibrium Path $(H / R=0.005$, Rise/Span=0.10) $\Lambda_{c r}$ : Timoshenko's Solution ${ }^{13)}$

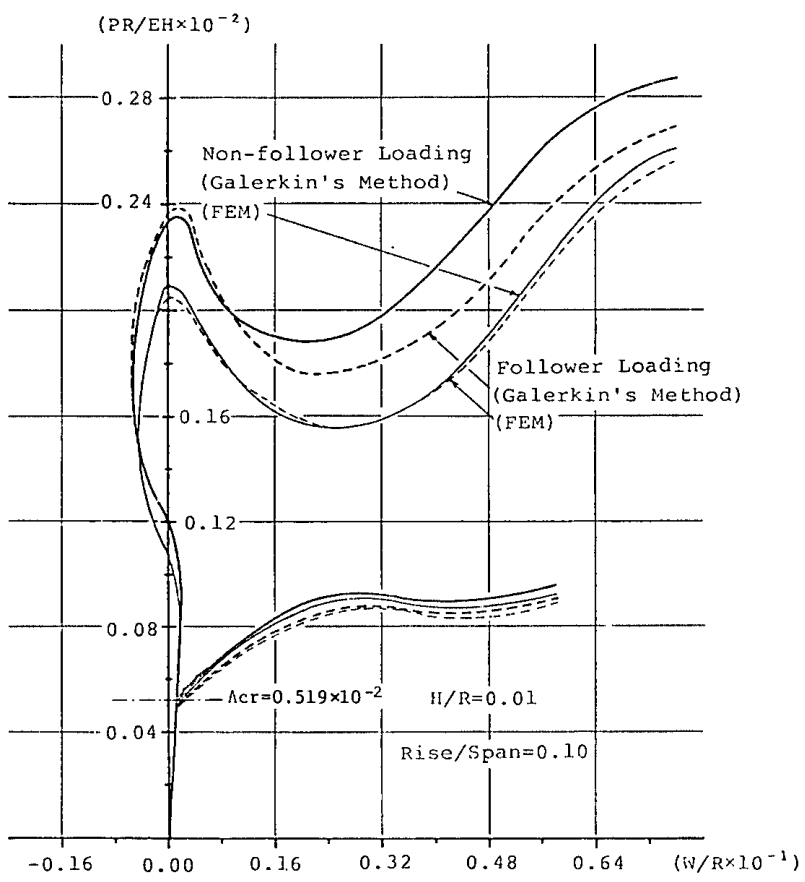

Fig. 4-5 Equilibrium Path $(H / R=0.01$, Rise/Span $=0.10)$ $\Lambda_{c r}:$ Timoshenko's Solution ${ }^{13)}$

ド法による結果は,FEM の結果と差異を持つものの, 分岐点付近までの結果については, 両者共良好な一致が 見られることが判る。

\section{5. 結 論}

本論では薄肉弾性体の安定限界に及ぼす外王の変形依 存性の影響を調べるために，モデルとして円弧ア一チを 採用し，静水圧の変形依存性を考慮した場合とここれを 無視した場合について直線ばり要素によるFEM と ノーマルモード法の 2 つの手法により解析を行い，これ らを比較検討した。以上の解析結果から次の各項目が結 論される。

（1）両端単純支持の円弧アーチが静水圧型の外力を

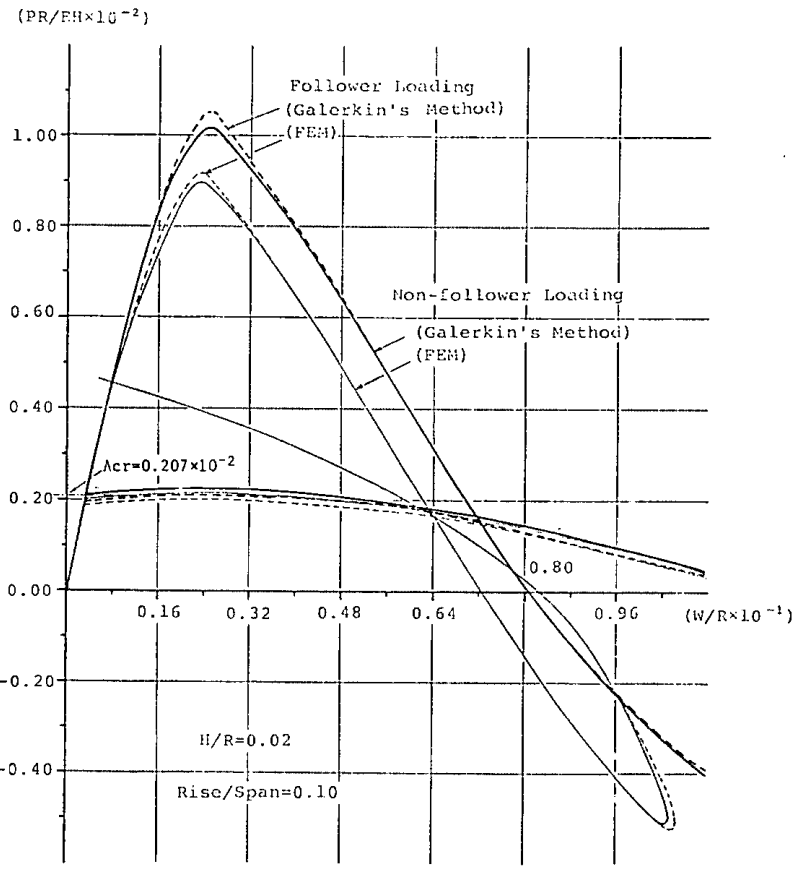

Fig. 4-6 Equilibrium Path $(H / R=0.02, \quad$ Rise/Span=0.10) $\Lambda_{c r}$ : Timoshenko's Solution ${ }^{(3)}$

受ける時, 釣合曲線上に現れる分岐点は, 定方向型の場 合と比べて低い荷重レベルに存在し，両者間の差異は, アーチが深く薄いほど大きくなる。

(2) メインパスについても，ア一チが深く薄いほ上゙ 両者に差異を生じ，また分岐点に比べて極めて高い位置 に飛移点が現れるようになる。

（3）円弧アーチが等分布外圧を受けた時，ライズ/ スパン比にして $1 / 20$ 程度を境目にして分岐点の性状が 変化する。すなわち，これより浅いアーチでは荷重漸減 型の不安定分岐点, 深いアーチでは荷重漸増型の安定分 岐点となる。しかし，安定分岐点となる場合でも，分岐 点からのわずかの荷重増加に対して, 分岐後飛移座屈を 生ずる場合がほとんどで，実際問題としては不安定点と 考えて良い。また，この性状は，外珐の形式によらず共 通のものである。

（4）この種の問題の分岐点探索のために用いられる 低波近似のノーマルモード法は，比較的良好な精度を保 持し得る。ただし，膜解を座屈前線形解とする線形固有 值問題としての扱いは，ア一チが深く薄いほど誤差を含 むものとなる。また，分岐点以降のメインパス上では低 次モードでは表現できない局部的変形が生じ，ノーマル モード法は大きな誤差を含むようになる。

以上の議論は, 線材の, しかも円弧ア一チというごく 限られたモデルに対するものであり，面材，例えば球形 シェル，円筒シェルに対する，外力の特性の限界荷重に 及ぼす影響については，一概には推測し難い。現に球形 シェルについては，これらの外力の形式の相違は，ほ之 んど結果に影響を及ぼさぬという報告 ${ }^{14)}$ ，あるいは，定 
方向型外力の方が，静水圧型外力よりも低い限界値を与

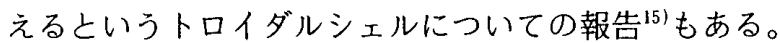

境界条件や初期不整のような，不確定的要因を伴う場 合と異なり，この外力形式の相違については，かなりの ところまで理論的に議論できるものと考えられる。しか し，こうした一般的見地に立った議論については，今後 の研究に待つところが大である。

\section{謝 辞}

本研究の遂行に当り，千葉大学・田中尚教授，東京 大学生産技術研究所・半谷裕彦教授には臨機の有益な御 助言を賜わった。ここに記して深甚の謝意を表する。

\section{参考文献}

1) B. Budiansky and J. W. Hutchinson: A Suvuey of Some Bukling Problems, AIAA J., Vol.4, No.10, 1966, p. 1505

2）砂川 恵：球形款の座屈に関する最近の研究動向, 日本 航空宇宙学会誌，第 16 巻，174 号，1968

3）小久保邦雄, 山本善之：球壳の座屈に及ぼす境界条件の 影響，日本機械学会誌，第 581 号，1981

4）内山和夫，山田大彦：外圧を受ける偏平球壳の座属に及 ぼす形状初期不整の影響, 昭和 48 年日本建築学会大会学 術講演梗概集, pp. 565 566

5）半谷裕彦，川股重也：座屈点に及ぼす初期不整の影響, 日本鋼構造協会第 7 回大会研究集会, 昭和 48 年, pp. $373 \sim 380$

6) H. Tsien : A Theory for the Buckling of Thin Shells, J. Aeronautical Sciences, Vol.9, 1942, pp. 373 384

7) G. W. H. Stevens: The Stability of a Compressed Elastic Ring and of a Flexible Heavy Structure spread by a System of Elastic Ring. Quart. J. Mech. Appl. Math., Vol. 5, No. 2, 1952, pp. 221 236

8) A.P. Boresi : A Refinement of the Theory of Buckling of Rings under Uniform Pressure, J. Appl. Mech., Vol. 22, No. 1, 1955, pp. 95 102

9) G.A. Wempner and N.E. Kesti : On the Buckling of Circular Arches and Rings, 4th U.S. Natl. Congr. Appl. Mech., Vol. 2, 1962, pp. 843 849

10) C. Oran and R.S. Reagan: Buckling of Uniformly Compressed Circular Arches, Proc. ASCE, Vol.95, No. EM4, 1969, pp. 879 - 895

11) L. M. Miline-Thomson: Theoretical Hydrodynamics, 5th Ed., Macmillan and Co. Ltd., London, 1968

12) Y. Hangai and S. Kawamata: Analysis of Geometrically Nonlinear and Stability Problems by Static Perturbation Method, Report of the Institute of Industrial Science, Unirevsity of Tokyo, Vol. 22, No. 5, 1973, pp. 246 294

13) S.P. Timoshenko and J. M. Gere : Theory of Elastic Stability, 2nd Ed., McGraw-Hill, New York, 1961

14）角野晃二, 小沢善隆：周辺固定支持部分球形殻の座屈解 析一周辺支持条件の緩和を含む一，日本建築学会論文報 告集. 第 325 号, 昭和 58 年, pp. 47 56

15）田波徹行, 坪井善勝：トロイダルシェルに関する基礎的 研究, 日本建築学会論文報告集, 第 335 号, 昭和 59 年, pp. $22 \sim 31$
16）戸川隼人：マトリクスの数値計算, オーム社, 1971, p. 41

17）細野 透：弧長法による弾性座屈問題の解析，その 1 , 日本建築学会論文報告集，第 243 号，1976

18）大森博司：変形依存型外荷重を受ける弾性体の安定問題, 東京大学学位論文, 1982

19）クーラン・ヒルベルト：数理物理学の方法 I, 東京図書, (丸山滋弥訳)，1975，pp. 185 187

付録 1 微小六面体の体積の変位ベクトルによる表示 本文中, Fig. 2-1 に示す微小六面体の体積 $\Delta V$ は次のように して求められる。

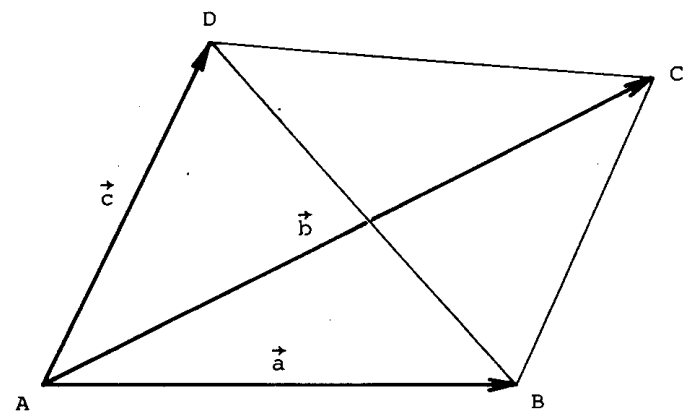

Fig. A-1 Tetrahedron with $\vec{a}, \vec{b}, \vec{c}$

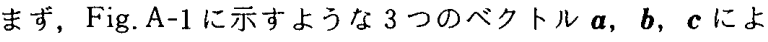
り作られる四面体の体積 $V_{\mathrm{ABCD}}$ は次式で表される。

$$
V_{\mathrm{ABCD}}=\frac{1}{6}\left|\begin{array}{lll}
a_{1} & a_{2} & a_{3} \\
b_{1} & b_{2} & b_{3} \\
c_{1} & c_{2} & c_{3}
\end{array}\right| \stackrel{d}{=} \frac{1}{6}\left|\begin{array}{l}
\boldsymbol{a} \\
\boldsymbol{b} \\
\boldsymbol{c}
\end{array}\right|=\frac{1}{6} \boldsymbol{a} \cdot(\boldsymbol{b} \times \boldsymbol{c})
$$

この表現を用いて Fig. 2-1 の六面体の体積を求めるために，こ れを 6 個の四面体に次のように分割する。

( $\left.\mathrm{P}^{\prime} \mathrm{PQS}\right),\left(\mathrm{P}^{\prime} Q Q^{\prime} \mathrm{S}^{\prime}\right),\left(\mathrm{P}^{\prime} Q \mathrm{~S}^{\prime} \mathrm{S}\right),\left(\mathrm{S}^{\prime} \mathrm{S} Q R\right)$,

$\left(S^{\prime} Q Q^{\prime} R^{\prime}\right),\left(S^{\prime} Q R^{\prime} R\right)$

このようにした上で，それぞれの四面体に(A-1) 式を用いて 微小六面体の体樻 $\Delta V$ を表せば,

$$
\begin{aligned}
& \Delta V=\frac{1}{6}\left(\left|\begin{array}{c}
\overrightarrow{P P^{\prime}} \\
\frac{\overrightarrow{Q P^{\prime}}}{S P^{\prime}}
\end{array}\right|+\left|\begin{array}{c}
\overrightarrow{Q P^{\prime}} \\
\frac{Q^{\prime} P^{\prime}}{S^{\prime} P^{\prime}}
\end{array}\right|+\left|\begin{array}{c}
\overrightarrow{Q P^{\prime}} \\
\frac{\vec{S}^{\prime} P^{\prime}}{S P^{\prime}}
\end{array}\right|+\left|\begin{array}{l}
\overrightarrow{S S^{\prime}} \\
\frac{\overrightarrow{Q S^{\prime}}}{R S^{\prime}}
\end{array}\right|\right. \\
& +\left|\frac{\overrightarrow{Q^{\prime}}}{\frac{\vec{Q}^{\prime} S^{\prime}}{R^{\prime} S^{\prime}}}\right|+\left|\frac{\overrightarrow{Q S^{\prime}}}{\frac{R^{\prime} S^{\prime}}{R S^{\prime}}}\right| \mid
\end{aligned}
$$

本文（2-2）式を用いて上式を展開すれば次式で得る。

$$
\begin{aligned}
\Delta V= & \boldsymbol{u} \cdot\left\{g_{1} \times g_{2}+\frac{1}{2}\left(\boldsymbol{u}_{, 1} \times g_{2}-u_{, 2} \times g_{1}\right)+\frac{1}{3} \boldsymbol{u}_{, 1} \times \boldsymbol{u}_{, 2}\right\} \\
& \cdot \Delta x^{1} \Delta x^{2}+g_{1} \cdot\left(\frac{1}{2} g_{2} \times u_{, 1}+\frac{1}{3} u_{, 2} \times u_{, 1}\right)\left(\Delta x^{1}\right)^{2} \Delta x^{2} \\
& +g_{2} \cdot\left(\frac{1}{2} u_{, 2} \times g_{1}+\frac{1}{3} u_{, 2} \times u_{, 1}\right) \Delta x^{1}\left(\Delta x^{2}\right)^{2} \cdots \cdots(\mathrm{A}-3)
\end{aligned}
$$

この表式中 $\Delta x^{1}, \Delta x^{2}$ に関して一次の項以外は高次の微小項と して省略できる。ゆえに，

$$
\begin{aligned}
d V= & \boldsymbol{u} \cdot\left\{\boldsymbol{g}_{1} \times \boldsymbol{g}_{2}+\frac{1}{2}\left(\boldsymbol{u}_{1,} \times \boldsymbol{g}_{2}-\boldsymbol{u}_{, 2} \times \boldsymbol{g}_{1}\right)\right. \\
& \left.+\frac{1}{3} \boldsymbol{u}_{11} \times \boldsymbol{u}, 2\right\} d x^{1} d x^{2} \ldots \ldots \ldots \ldots \ldots .
\end{aligned}
$$

となり，考えている弾性体表面全面について積分することによ 
り全体積 $V$ は次式のように与えられる。

$$
\begin{aligned}
V= & \iint_{s} \boldsymbol{u} \cdot\left\{\boldsymbol{g}_{1} \times \boldsymbol{g}_{2}+\frac{1}{2}\left(\boldsymbol{u}_{1,} \times \boldsymbol{g}_{2}-\boldsymbol{u}_{, 2} \times \boldsymbol{g}_{1}\right)\right. \\
& \left.+\frac{1}{3} \boldsymbol{u}_{, 1} \times \boldsymbol{u}, 2\right\} d x^{1} d x^{2} \ldots \ldots \ldots \ldots \ldots \ldots \ldots \ldots \ldots \ldots \ldots \ldots
\end{aligned}
$$

付録 2 直線はり要素における静水圧の仕事の表示式 一要素当りの静水圧外力による仕事 $W \mathbf{t}$ は次式で与えられる。

$$
W^{e}=\Lambda b A
$$

ここに, $\Lambda$ は圧力の大きさ (一定)， $b$ ははり幅， $A$ は外力を受 けて平面はり要素が移動した部分の面積を表す。

この面積 $A$ は, 平面上の曲線座標を $x^{1}$ とすれば, 本文 (2-4) 式から次のように求められる。

$$
A=\int_{x^{1}} u \cdot\left(g_{1} \times g_{2}+\frac{1}{2} u_{, 1} \times g_{2}\right) d x^{1}
$$

ここに, $\boldsymbol{g}_{1}$ は $x^{1}$ 方向の, $\boldsymbol{g}_{2}$ は $\boldsymbol{u}$ 之 $\boldsymbol{g}_{1}$ の張る平面に垂直かつ右 手系を成す方向の，それぞれ共変基底べクトルであり，uは変 位ベクトルである。この表現を直線はり要素の表現に置き換え るために次のように置く。

$$
g_{1}=i, \quad g_{2}=j, \quad u=\left(u^{1}, u^{2}\right)=(u,-w),
$$$$
x^{1}=s
$$

ここに，iおよび $\boldsymbol{j}$ はそれぞれの方向の単位ベクトル，u, $w$ お よび $s$ はFig. 3-1 に示す変位および座標である。この表現を (A-7) 式に用いれば次式を得る。

$$
A=\int_{0}^{l}\left\{w+\frac{1}{2}\left(w \frac{d u}{d s}-u \frac{d w}{d s}\right)\right\} d s
$$

ここに,lは要素の長さを表す。

上式を直線はり要素の変位関数を用いて離散化する。変位関 数は次式で表される。

$$
\left.\begin{array}{l}
u(\xi)=N_{11}(\xi) u_{i}+N_{12}(\xi) u_{j} \\
w(\xi)=N_{21}(\xi) w_{i}+N_{22}(\xi) w_{j}+M_{11}(\xi) \theta_{i}+M_{12}(\xi) \theta_{j}
\end{array}\right\}
$$

ここに, $\xi=s / l$ であり, $u_{i}, w_{i}, \theta_{i}$ は要素端点 $i の, u_{j}, w_{j}$, $\theta$ ，は要素端点 $j$ の，それぞれ要素座標系での軸方向変位, 面外 方向変位, 回転角を表し, $N_{11}, N_{12}$ 等はエルミート補間の係数 で次式で表される。

$$
\begin{aligned}
& N_{11}(\xi)=1-\xi, \quad N_{12}(\xi)=\xi \\
& N_{21}(\xi)=(1+2 \xi)(1-\xi)^{2}, \quad N_{22}(\xi)=(3-2 \xi) \xi^{2} \\
& M_{11}(\xi)=l \xi(1-\xi)^{2}, \quad M_{12}(\xi)=l(\xi-1) \xi^{2}
\end{aligned}
$$

要素座標系での節点変位ベクトルを $\left\{d^{e}\right\}$ とし, その並びは次の とおりであるものとする。

$$
\left\{d^{e}\right\}^{T}=\left[u_{i}, w_{i}, \theta_{i}, u_{j}, w_{j}, \theta_{j}\right]
$$

節点力ベクトルを $\Lambda\left|F^{e}\right|$ とすれば，一要素当りの離散化された 外力仕事は次式のように表される。

$$
W^{e}=\Lambda\left|F^{e q}\right| d^{e} \mid \cdots
$$

(A-10) 式を(A-9) 式に用い,さらにこれを(A-6) 式に用い て (A-13) 式と比較す机ば，節点力ベクトル $\left\{F^{e}\right\}$ は次のように 求められる。

$$
\left\{F^{e}\right\}=\left[E^{e}\right]\left\{d^{e}\right\}+\left\{P^{e}\right\}
$$
ここに,

$$
\left[E^{e}\right]=b\left[\begin{array}{cccccc}
0 & 0 & -l / 12 & 0 & -1 / 2 & l / 12 \\
& 0 & 0 & 1 / 2 & 0 & 0 \\
& & 0 & l / 12 & 0 & 0 \\
& \text { sym. } & & 0 & 0 & -l / 12 \\
& & & & 0 & 0 \\
& & & & & 0
\end{array}\right]
$$$$
\left\{P^{e}\right\}^{r}=b\left[0, l / 2, l^{2} / 12,0, l / 2,-l^{2} / 12\right]
$$

付録 3 帯行列を用いた弧長法

通常の弾性非線形問題の基礎式は次式で表される。

$\left.\left.\left.\left[K_{i j}\right]\left\{d_{j}\right\}+\left[K_{i j k}\right] \mid d_{j}\right\}\left|\left\{d_{k}\right\}+\left[K_{i j k l}\right]\left\{d_{j}\right\}\right| d_{k}\right\}\left|d_{d}\right|=\lambda \mid P_{i}\right\}$

この式の増分過程における修正方程式は次式となる。

$\left.\left[K_{i j}^{*}\right]\left\{\Delta d_{j}\right\}-\Delta \lambda \mid P_{i}\right\}=\left\{F_{d}\right\}$

ここに, $\left[K_{i j}^{*}\right]=\left[K_{i j}\right]+\left(\left[K_{i j k}\right]+\left[K_{i k j}\right]\right)\left\{d_{d j}^{0}\right\}+\left(\left[K_{i j k t}\right]+\left[K_{i k j t}\right]\right.$ $\left.+\left[K_{\text {ilk }}\right]\right)\left\{d_{k}^{0}\right\}\left\{d_{\text {? }}^{\text {? }}\right\}$

$\left.\mid F_{d}\right\}=-\left(\left[K_{i j}\right]\left\{d_{j}^{0}\right\}+\left[K_{i j k}\right]\left\{d_{j}^{0}\right\}\left\{d_{k}^{0}\right\}+\left[K_{i j k l}\right]\left\{d_{j}^{0}\right\}\left\{d_{d}^{0}\left\{d_{l}^{0}\right\}\right.\right.$ $-\lambda^{0}\left\{P_{i} \mid\right)$

ただし， $\left|d_{j}^{0}\right| 、 \lambda^{0}$ 等は，この段階までに求められた既知べクトル とする。次に，弧長条件式は次式で与えられる。

$$
\sum_{i}\left(d_{i}-d_{i}^{0}\right)^{2}+\left(\lambda-\lambda^{0}\right)^{2}=r^{2}
$$

この式に対応する修正方程式は次式で与えられる。

$$
\sum_{i}\left(d_{i}-d_{i}^{0}\right) \Delta d_{i}+\left(\lambda-\lambda_{0}\right) \Delta \lambda=f
$$

ここに, $f=(1 / 2)\left\{r^{2}-\sum_{i}\left(d_{i}-d_{i}^{0}\right)^{2}-\left(\lambda-\lambda_{0}\right)^{2}\right\}$

（A-16）式と（A-18）式をまとめてマトリクス表示すれば,

$$
{ }^{N}\left[\begin{array}{cc}
{\left[K_{t j}^{*}\right]} & \left|-P_{t}\right| \\
\left|d_{i}-d_{i}\right| T & \lambda-\lambda_{0}
\end{array}\right]\left\{\begin{array}{c}
\left|\Delta d_{J}\right| \\
\Delta \lambda
\end{array}\right\}=\left\{\begin{array}{c}
\left|F_{i}\right| \\
f
\end{array}\right\} \cdots \cdots
$$

ここで, [K $\left.K_{i j}^{*}\right]$ は通常バンド化され得るが, $N$ 行と $N$ 列が値を 持ち, かつ非対称となっており, 全体としてはバンド的性格の ない非対称マトリクスとなっている。ここで, 次のマトリクス を考える。

$$
\left[\begin{array}{cc}
{[A]} & \mid a\} \\
\left\{\left.b\right|^{\top}\right. & c
\end{array}\right]
$$

ここで, $[A]$ は $m \times m$ の正方マトリクス, $\{a|| b \mid$, は $m \times 1$ のべ クトル，cはスカラーとする。

(A-20) 式で表されるマトリクスの逆マトリクスは, 次式で与 えられる16)。

$$
\begin{aligned}
& {\left[\begin{array}{cc}
{[A]} & \{a\} \\
\left\{\left.b\right|^{r}\right. & c
\end{array}\right]^{-1}} \\
& =\left[\begin{array}{cc}
{[A]^{-1}+[A]^{-1}|a|\{b\}^{\top}[A]^{-1 / k}} & -[A]^{-1}|a| / k \\
-\{b\}^{\top}[A]^{-1} / k & 1 / k
\end{array}\right]
\end{aligned}
$$

ここに, $k=c-|b|^{T}[A]^{-1}\{a \mid$

これを用いれば，(A-19）式は形式的に次式のように解くこと ができる。

$$
\begin{aligned}
& \left\{\begin{array}{c}
\left|\Delta d_{i}\right| \\
\Delta \lambda
\end{array}\right\} \\
& =\left\{\begin{array}{c}
{\left[K_{i j}^{*}\right]^{-1}\left(\left\{F_{d}\right\}+\left|-P_{i}\right|\left|d_{i}-d_{i}^{0 T}\left[K_{i j}^{*}\right]^{-1}\right| F_{i} \mid / \tilde{k}-\left\{P_{i} \mid \cdot f / \tilde{k}\right)\right.} \\
\left(-\left\{d_{i}-d_{i}^{0}\right\}^{T}\left[K_{i j}^{*}\right]^{-1}\left\{F_{b}\right\}+f\right) / \tilde{k}
\end{array}\right\}
\end{aligned}
$$

ここに, $\tilde{k}=\left(\lambda-\lambda^{0}\right)-\left\{d_{i}-\left.d_{i}^{0}\right|^{\top}\left[K_{i j}^{*}\right]^{-1}\left\{-P_{i}\right\}\right.$

ここで,

$$
\left\{x_{i}\left|=\left[K_{t j}^{*}\right]^{-1}\right| F_{j}\right\},\left|y_{i}\right|=\left[K_{i j}^{*}\right]^{-1}\left\{-P_{j}\right\}
$$

と置けば, (A-22) 式は次のようになる。

$$
\left\{\begin{array}{c}
\left|\Delta d_{d}\right| \\
\Delta \lambda
\end{array}\right\}=\left\{\begin{array}{c}
\left|x_{i}\right|+\left|y_{i}\right|\left|d_{i}-d_{i}^{0}\right|^{\top}\left|x_{i}\right| / \tilde{k}-\left|y_{d}\right| f / \tilde{k} \\
\left(-\left|d_{i}-d_{i}^{q}\right|^{r}\left|x_{i}\right|+f\right) / \tilde{k}
\end{array}\right\}
$$

ここに, $\tilde{k}=\left(\lambda-\lambda^{0}\right)-\left\{\dot{d}_{i}-d_{i}^{0}\right\}^{\top}\left|y_{i}\right|$

上式は単にベクトルの乗算のみから成っており，(A-23) 式 が解ければ求められる。ところが, (A-23) 式は, 係数マトリ クスとして $\left[K_{i j}^{*}\right]$ のみを持つ連立方程式であるから, 対称バン ドマトリクスとしての扱いが可能である。したがって、こうし 
た手法を用いれば，弧長法とバンドマトリクスの双方を用いて 解析することが可能となる。

付録 4 分岐操作について ${ }^{171}$

通常の幾何学的非線形解析における増分方程式は次式のよう に表される。

$[K]\{\Delta d\}-\Delta \lambda\{P\}=\{0\}$

ここに, $[K]$ は増分剛性マトリクス， $\{\Delta d\} ， \Delta \lambda$ はそれぞれ増分 変位ベクトル, 增分荷重パラメーター, $\{P \mid$ は荷重ベクトルを表 す。

分岐点においては，係数マトリクスの行列式が消失するゆえ， $\operatorname{det}[K]=0$ $(A-26)$

この時のマトリクス $[K]$ の退化次数が 1 であり，マトリクス $[K]$ $[$ 一行一列を除いて得られる部分マトリクス $[\tilde{K}]$ は非特異 であるしすれば,

$$
\operatorname{det}[\bar{K}] \neq 0
$$

これを用いて，(A-25) 式を次式のように書き直す。

$$
\left[\begin{array}{cc}
K_{11} & \left\{\left.\bar{K}\right|^{T}\right. \\
\{\bar{K}\} & {[\tilde{K}]}
\end{array}\right]\left\{\begin{array}{c}
\Delta d \\
\{\Delta \tilde{d}\}
\end{array}\right\}-\Delta \lambda\left\{\begin{array}{c}
P_{1} \\
\{\tilde{P}\}
\end{array}\right\}=|0|
$$

(A-27) 式の条件の下で, 上式を $\{\Delta \tilde{d}\} に$ にいて解くと,

$\left\langle\Delta \tilde{d}\left|=[\tilde{K}]^{-1}\left(-|\bar{K}\rangle \Delta d_{1}+\Delta \lambda \mid \tilde{P}\right\}\right)\right.$

この表現を(A-28) 式の第一式に用いると，

$$
\Delta \lambda\left(P_{1}-\{\bar{K}\}^{T}[\tilde{K}]^{-1}\{\tilde{P}\}\right)=0
$$

ここで, $g=P_{1}-\left\{\left.\bar{K}\right|^{T}[\tilde{K}]^{-1}\{\tilde{P}\}\right.$ と置くと次の 2 つのケースがあ り得る。

( i ) $g \neq 0$ の時

この時は $(A-30)$ 式から

$$
\Delta \lambda=0
$$

ゆえに，(A-29) 式から，

$$
\left\{\Delta d \mid=\left\{\begin{array}{c}
d_{1} \\
\{\Delta \tilde{d}\}
\end{array}\right\}=d_{1}\left\{\begin{array}{c}
1 \\
\left.-[\tilde{K}]^{-1} \mid \bar{K}\right\}
\end{array}\right\}\right.
$$

ここに， $d_{1}$ は任意の定数。

(ii) $g=0$ の時

同じく $(A-29)$ 式から,

$$
\left\{\Delta d \mid=\left\{\begin{array}{c}
d_{1} \\
|\Delta \tilde{d}|
\end{array}\right\}=d_{1}\left\{\begin{array}{c}
1 \\
\left.-[\tilde{K}]^{-1} \mid \bar{K}\right\}
\end{array}\right\}+\Delta \lambda\left\{\begin{array}{c}
0 \\
{[\tilde{K}]^{-1}|\tilde{P}|}
\end{array}\right\}\right.
$$

以上のように, 分岐方向ベクトル $\{\Delta d \mid$ は, $[\tilde{K}]$ を係数マトリ クス，荷重項を $|\bar{K}|$ とする連立方程式を解くことにより，固有 値解析等の特別な手続きを経ることなく得ることができ， $[\tilde{K}]$ の持つ対称バンド性も手伝って, 分岐操作を極めて簡略化する ことが可能となる。

付録 5 つり合点の安定性について

本論で示されているつり合曲線上の各つり合点はそのつり合 方程式，すなわち次式を満足している。

$$
\left(K_{i j}-\Delta \Lambda E_{i j}\right) d_{s}+K_{i j k} d_{j} d_{k}+K_{i j k \imath} d_{j} d_{k} d_{\imath}=\Lambda P_{\imath} \quad(\mathrm{A}-34)
$$

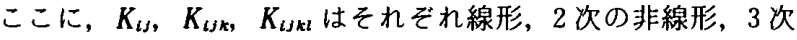
の非線形の剛性行列， $d_{l}$ は変位ベクトル， $P_{l}$ は通常の荷重モ一 ドベクトル， $E_{l j}$ は静水圧型外力の従動性を表す行列， $\Lambda$ は荷 重レベルを表すパラメーターであり， $\Delta$ は非従動的外力の場合 は 0 , 従動的外力の場合は 1 となる便宜的なパラメーターであ る。また，本文同様，添字には総和規約を用いている。

今，各釣合点の安定性を検討するために，つり合点 $\left(\bar{d}_{i}, \bar{\Lambda}\right)$ において微小振動法を適用する。その際の基礎式は，(A-34) 式に慣性項を導入して得られる非線形運動方程式の第一変分式 として次式のように与えられる。

$$
M_{i s} \ddot{\xi}_{s}+\bar{K}_{i s} \xi_{j}=0
$$

ここに, $\bar{K}_{\imath \jmath}=\left(K_{i j}-\Delta \bar{\Lambda} E_{i j}\right)+\left(K_{i j k}+K_{i k j}\right) \bar{d}_{k}+\left(K_{i j k l}+K_{i k j l}+\right.$

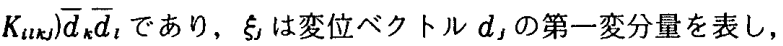
ドットは時刻に関する微分を表す。

ここで $M_{i j}$ は正值定符号の対称行列， $\bar{K}_{\iota}$ はここでは正値性の 不明な対称行列である。上式を後の議論に便利なように次のよ うに行列表示にしておく。

$[M]|\ddot{\xi}|+[\bar{K}]\{\xi \mid=\{0\}$

ここで $|\xi|$ を次のように置いて時刻坐標を分離する。 $\{\xi(t)\}=|x| e^{i \omega t}$

ここに $i$ は虚数単位, $\omega$ は角振動数, $t$ は時刻を表すパラメー ターである。この表現から明らかなように, 今問題としている つり合点は, $\omega か ゙$ 実数の時安定， $\omega$ が虚数の時（正確には負の 虚数であるが, 後述するように, 根 $\omega$ は必ず共役性を伴って現 れる) 不安定と判定されることになる。

(A-37) 式を(A-36) 式に用いれば, 次式の一般固有值問題を 得る。

$$
[\bar{K}]\{x\}=\omega^{2}[M]|x|
$$

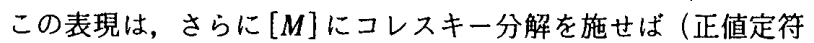
号性より常に可能), 次式のような標準固有値問題に帰着される。

$\left.[A]\{y\}=\omega^{2} \mid y\right\}$ $(A-39)$

ここに, $\left.[A]=\left([R]^{-1}\right)^{T}[\bar{K}][R]^{-1}, \quad \mid y\right\}=[R]|x|$

$$
[M]=[R]^{T}[R],[R] \text { : 上三角行列 }
$$

結局、ここに現れる係数行列 $[A]$ の固有値を調べることによ

$$
\begin{aligned}
& \mathrm{s}^{+} \text {: Stable Path } \\
& \mathrm{U}^{-}: \text {Unstable Path with One Negative Eigenvalue } \\
& \mathrm{U}^{--} \text {: Unstable Path with Two Negative Eigenvalues } \\
& { }^{*}: \text { Turning Point of Stability }
\end{aligned}
$$

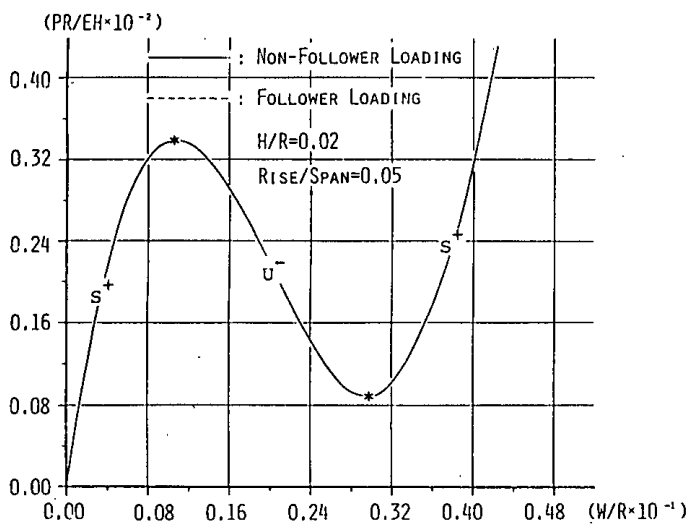

Fig. A-2 Stability of Equilibrium Path

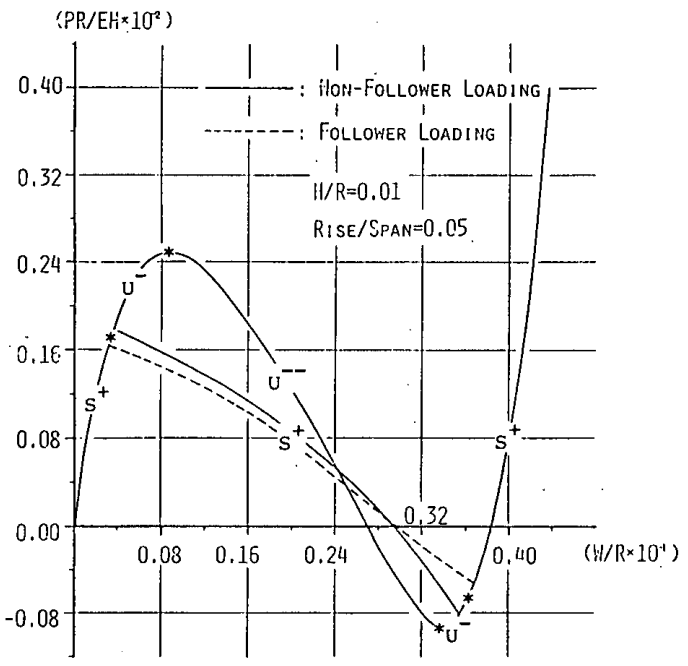

Fig. A-3 Stability of Equilibrium Path 


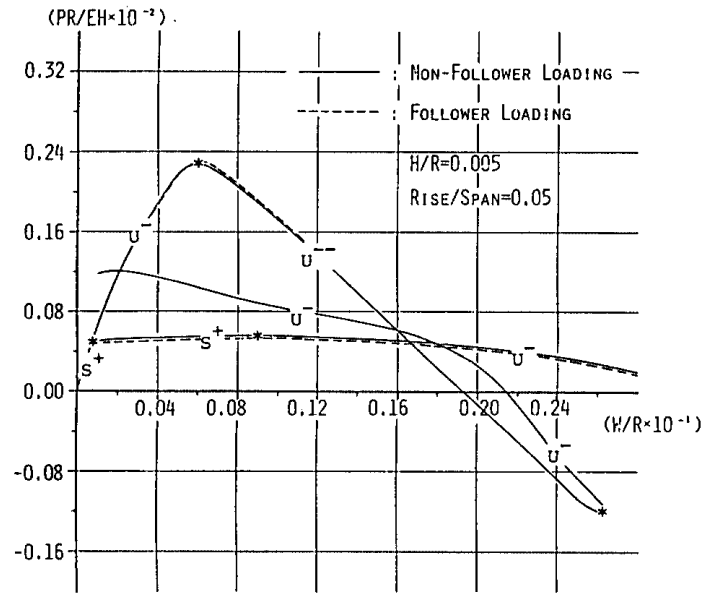

Fig. A-4 Stability of Equilibrium Path

り，系のつり合点の安定性が検討されることになる。係数行列 $[A]$ は実対称行列であるゆえ, その固有値 $\omega^{2}$ は実数之なること が保証される。したがって，ここでは $(\mathrm{A}-39)$ 式の固有值問題

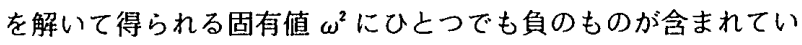
れば，これに対応する共役虚根 $\omega に$ に負の虚数が出現するため， 問題としているつり合点は不安定と判定されることとなる。

以上のように, 系のつり合点の安定, 不安定の検討は, (A-39) 式で表現される固有値問題に率着された。ここに示されている 係数行列 $[A]$ は, 質量行列 $[M]$ をコレスキー分解して得られる 上三角行列 $[R]$ の逆行列を変換行列とする, 增分剛性行列 $[\bar{K}]$ の実非特異合同変換により得られている。行列理論におけるシ ルヴェスターの慣性律副によれば, 実非特異合同変換は, 元の

注 1）慣性律もしくは慣性定理と呼ばれるもので，たとえば R. ツルミュール：マトリクスの理論と応用(ブレイン 図書)，pp. 127-130を参照されたい。
行列のランクおよび指数（基本変形により得られる対角行列の 正項の数) を不変に保つことが示される（ただし, 固有值の絶 対值は変化する)。今，ここで問題としているのは, 係数行列 $[A]$ の固有値そのものではなく，その符号であることに注意す れば，(A-39）式を解く代わりに次式，すなわち

$$
[\bar{K}]|z|=\lambda\{z\}
$$

で表される固有値問題を解いて, 固有値 $\lambda$ の符号を調べれば, 元の係数行列 $[A]$ の固有値の符号の分布をとらえることができ ることが，上記の慣性律により保証されていることが判る。こ のように, 保存的な系洋2)のつり合点の安定性を微小振動法を用 いて調べる時, しいて質量行列を導入することなく, 単に增分 剛性行列の固有值の符号を調べれば十分であることが明らかと なる。なお, 増分剛性行列の行列式の符号を用いて安定判別を 行うことは, 上述の議論からも明らかなように, 安定, 不安定 の移行点で増分㴊性行列のランクが偶数次数变化する場合には 不都合となる。

以上の考え方に基づき, 本論第 3 章で示しているつり合曲線 につき，その安定性の検討を行った。結果の一部をFig. A-2 Fig. A-4 に示す。図中 $S^{+}$と示すパスは $(A-40)$ 式の固有值 $\lambda$ がすべて正であり安定と判定されたものであり，U一更よび $U^{--}$はそれぞれ 1 個および 2 個の負の固有値が出現し, 不安定 と判定されたものであることを,さらに*印はそれらの移行点 を表している。これらの図から, 分岐点直後の分岐パスは安定 であるが, Fig.A-4 の場合のように，荷重増加型の分岐点（従 来この形式を安定分岐点と呼んでおり，本文中ではこれを踏祖 している) においては, 荷重减少に移行する点で不安定へと移 行する，いわゆる分岐バス上での飛移点が存在することもある ことが判る。

注 2）増分剛性行列 $[\bar{K}]$ の対称性が保証されている場合に限 定するという意味で特に断わった。 


\section{SYNOPSIS}

UDC : $624.074 .32: 624.074 .43: 624.042$

\section{ELASTIC STABILITY PROBLEM OF CIRCULAR ARCHES SUBJECTED TO HYDROSTATIC PRESSURES}

by Dr. HIROSHI OHMORI, Research Associate of Nagoya Univ., Member of A.I. J.

Stability problem of thin elastic structures subjected to the external pressure have been discussed by many researchers. In most of these researches, characteristics of the configuration dependency of the external pressure have been thoughtlessly ignored, in spite of their rather large influencies which was firstly pointed out by H. Tsien.

In this paper, the geometrically nonlinear analysis of the elastic circular arch with both ends hinged is carried out by both of the finite element method and the normal mode technique, in order to grasp the influence of the characteristics of the configuration dependency of the external pressure on the critical state of the elastic system. And there, the exact potential expression of the hydrostatic pressure connected with the displacements of the elastic system in the general curvilinear coordinate is derived and the direct descretization of this expression is used in the numerical analysis. From the results of these analyses, the following conclusions are obtained :

(1) the bifurcation buckling occurs at the lower pressure level in the case of the hydrostatic pressure compared with the constant directional one, in the deep and thin circular arches.

(2) the snap-through point comes to locate itself in the much higher pressure level than one of the bifurcation point in the deep and thin circular arch and both types of the external pressure. have the same tendency.

(3) the normal mode method can maintain the relatively good accuracy to search the bifurcation point of these types of the external loads. 